\title{
Ergenlerde Akıllı Cep Telefonunun Problemli Kullanımını Azaltmaya Yönelik Bir Psikoeğitim Programının Etkililiğinin İncelenmesi ${ }^{1}$
}

\author{
DOI: 10.26466/opus.621117
}

\author{
* \\ Mustafa Pamuk ${ }^{*}$ - Mustafa Kutlu** \\ * Dr, Öğr. Üyesi Selçuk Üniversitesi, Eğitim Fakültesi Selçuklu / Konya/ Türkiye \\ E-Posta: mustafa.pamuk@selcuk.edu.tr ORCID: 0000-0001-8367-4382 \\ ** Prof. Dr., İnönü Üniversitesi, Eğitim Fakültesi, Merkez / Malatya/ Türkiye

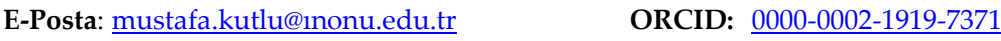

Öz

Bu araştırmanın amacı günümüzde ergenlerin yaşamında birçok açıdan ( $p$ sikolojik ve fiziki sağlık, akademik, finansal, toplumsal vb) önemli bir problem haline gelmeye başlayan akıll telefonlarm problemli kullanımın azaltmaya dönük hazırlanan psikoeğitim programının etkililiğini incelemektir. Araştırmada iç içe karma desen kullanılmıştır. Araştırmada ortalama, standart sapma, Kruskal Wallis H Testi, Friedman Mertebeler Testi, Wilcoxon İşaretli Stralar Testi, Mann-Whitney U Testi ve içerik analizi kullanılmıştır. Oturumların hazırlanmasında ergenler, veliler ve rehber öğretmenlerle yapılan görüşmeler ve ilgili alanyazın dikkate alınmıştır. Hazırlanan 11 oturumluk psikoeğitim programının ergenlerde akıllı cep telefonunun problemli kullanımını azaltmadaki etkililiğini test amactyla $3 \times 3$ 'lük (deney, kontrol ve plasebo X öntest-sontest-izleme testi) split plot faktöryel desen kullanlmıştır. Araştırmanın deney, kontrol ve plasebo gruplarında 10'ar ortaöğretim öğrencisi yer almıştır. Elde edilen bulgulara göre uygulanan 11 oturumluk psikoeğitim programının ergenlerde akıllı telefonların problemli kullanımın azaltmada etkili olduğu bulunmuştur. Ayrıca programın bitişinde deney grubu öğrencilerinden grubun etkililiğine ilişkin alınan görüşlerin de programın etkili olduğunu yönündedir. Elde edilen bulgular tartışılmış ve bazı önerilerde bulunulmuştur.

Anahtar Kelimeler: Akıllı telefonların problemli kullanımı, psikoeğitim programı, ergenler, iç içe karma desen

\footnotetext{
${ }^{1}$ Bu çalışma Prof. Dr. Mustafa KUTLU danışmanlığında Dr. Mustafa PAMUK tarafından hazırlanan Doktora tezinden çıkarılmıştır.
} 


\title{
Examination of The Effectiveness of A Psychoeducation Program to Reduce The Problematic Use of Smartphone in Adolescents
}

\begin{abstract}
The aim of this study is to examine the effectiveness of the psychoeducation program designed to reduce the problematic use of smartphones, which has become an important problem in adolescents' lives in many aspects (psychological and physical health, academic, financial, social, etc.). Embedded mixed methods research design was used in the study. Mean, standard deviation, Kruskal Wallis H Test, Friedman Rank Test, Wilcoxon Signed Ranks Test, Mann-Whitney U Test and content analysis were used in the study. Interviews with adolescents, parents and guidance counselors and related literature were taken into consideration during the preparation of the sessions. In order to test the effectiveness of the 11-session psychoeducation program in reducing the problematic use of smartphones in adolescents, a $3 \times 3$ split-plot (experimental, control and placebo X pretest-posttest-monitoring test) was used. The experimental, control and placebo groups of the study included 10 high school students in each group. According to the findings, an 11-session psychoeducation program was found to be effective in reducing the problematic use of smart phones in adolescents. In addition, the opinions of the experimental group students about the effectiveness of the group at the end of the program is that the program is effective. The findings were discussed and some suggestions were made.
\end{abstract}

Keywords: $\quad$ Problematic use of smartphones, psychoeducation program, adolescents, embedded mixed method design 


\section{Giriş}

Günümüzde birçok insanın kullandığı teknolojik aletlerin başında cep telefonları gelmektedir. Cep telefonları, özellikle de akıllı cep telefonları, kişiler için konuşma, kısa mesaj yollayabilme, e-posta gönderebilme, internete bağlanma, sosyal ağlara bağlanabilme, fotoğraf ve video çekebilme, MP3 dinleme, tv izleyebilmenin yanısıra navigasyon olarak kullanabilme ve bankacılık işlemlerinde kullanabilme gibi birçok olanağı sunmaktadırlar (Pamuk ve Atli, 2016). Cep telefonlarının sunduğu bu hizmetlerden birçok insan yararlanmaktadır. Ancak bireyler cep telefonlarını yukarıda sayılan kolaylıklardan doğabilecek ihtiyaçlarını karşılamalarının dışında, aşırı ve gereğinden fazla kullanmaya başladıklarında cep telefonunun problemli kullanımı ortaya çıkabilmektedir.

Cep telefonlarının problemli kullanımına ilişkin araştırmaların geçmişi çok uzun olmamasına rağmen son yıllarda artış gösterdiği görülmektedir. Cep telefonlarının, özellikle de yeni nesil akıllı cep telefonlarının, internete bağlanma, oyun oynayabilme, tv izleyebilme, e-alı̧veriş yapabilme gibi olanakları sunması, bireyler için olumlu olabilmesinin yanında olumsuz da olabilmektedir. Çünkü bu sunulan her bir olanağa ilişkin olarak alanyazında internet bağımlılığı (Günüç ve Kayri, 2010), video oyun bağımlılığı (Chiu, Lee ve Huang, 2004; Lemmens, Valkenburg ve Gentile, 2015), tv bağımlılığı (Kubey ve Csikszentmihalyi, 2002), online alışveriş bağımlılı̆̆ (Wang ve Yang, 2007) şeklinde davranışsal bağımlılık türünde problemli kullanımlarına ilişkin araştırmalara rastlanmaktadır. Cep telefonunun birçok kişi tarafından farkedilmeyen bu yüzü, bireylerde cep telefonlarını problemli kullanma davranışını ortaya çımasına neden olabilmektedir. Ayrıca cep telefonunun kolay taşınabilir olması, mekân yönünden de çok fazla kısıtlı olmaması bireylerin cep telefonlarını problemli kullanım davranışlarını pekiştirebilmektedir.

Cep telefonunun problemli kullanımına ilişkin yapılan çalışmalar dikkate alındığında, bu konunun birçok farklı değişkenle çalışıldığı görülmektedir. İlgili alanyazın incelendiğinde; cep telefonunun problemli kullanımının yalnızlıkla (Mert ve Özdemir, 2018; Şar, 2013; Tan, Pamuk ve Dönder, 2013), özsaygiyla (Hong, Chiu ve Huang, 2012; Tohumcu, Karslı, Bahadır ve Kalender, 2019) depresyonla (Augner ve Hacker, 2012; Çağan, Ünsal ve Çelik, 2014; Özen ve Topcu, 2017), anksiyeteyle (Hong vd., 2012; Jenaro, Flores, Gomez-Vela, Gonzales-Gil ve Caballo, 2007; O'Connor vd., 
2013), dürtü kontrolüyle (O'Connor vd., 2013), stresle (Augner ve Hacker, 2012; Wang, Wang, Gaskin ve Wang, 2015), sosyal kaygiyla (Hayırc1, 2019; Yılmaz, Şar ve Civan, 2015), günlük yaşamda bilişsel hatalarla (Hadlington, 2015), uyku problemleriyle (Sahin, Özdemir, Ünsal ve Temiz, 2013; Yang, Yen, Ko, Cheng ve Yen, 2010), hiperaktiviteyle (Roser, Schoeni, Foerster ve Röösli, 2016), dışadönüklükle (Hong vd., 2012), akademik başarısızlıkla (Çağan vd., 2014), akademik ertelemeyle (Çetin, Pamuk ve Donmuş, 2015; Erdoğan, Pamuk, Yürük ve Pamuk, 2013) ilişkili olduğu bulunmuştur. İlgili alanyazın dikkate alındığında akıllı cep telefonlarının problemli kullanımlarının bireylerin yaşamlarına olumsuz etkileri olduğu görülmektedir.

Türkiye İstatistik Kurumu'nun (TÜIK) 2016 yılı hanehalkı bilişim teknolojileri kullanım araştırması verilerine göre, interneti en çok kullanan grubun ortaöğretime devam eden ergenlerin de içinde bulunduğu 16-24 yaş grubu olduğu belirtilmiştir. Bu durum dikkate alındığında günümüz ergenlerinin çağımızdaki teknolojik gelişmelere ayak uydurdukları şeklinde yorumlanabilir. Genel anlamda bu durum ergenler için avantaj olarak görülebilirken bazı ergenlerin teknolojiyi gereğinden fazla, aşırı kullanmaları sonucu bu durum dezavantaja dönüşebilmektedir. Ergenlerin kişilik gelişimi bağlamında savunmasız bir grup olmaları (KaltialaHeino, Lintonen ve Rimpelä, 2004), ergenleri teknolojinin gereğinden fazla, aşırı kullanılması sonucu ortaya çıkan dezavantajlı durumlar açısından daha riskli hale getirebilmektedir. Günümüzde ergenlerin kullandıkları teknolojik aletlerin başında akıllı cep telefonları gelmektedir. Akıllı cep telefonları birkaç tıkla bireylerin birçok ihtiyacını karşılayabilmektedir. Birçok olanağı kolay ve hızlı bir biçimde sunan akıllı cep telefonlarının gereğinden fazla, aşırı kullanımları bireylerde akıllı cep telefonunun problemli kullanımına neden olabilmektedir.

Akıllı cep telefonu kullanmaya eğilimli olan ergenlerin cep telefonlarını sağlıklı bir şekilde, işlevsel olarak kullanabilmelerinin hem ergenler hem aileler hem de toplum açısından önem arz ettiği düşünülmektedir. İlgili alanyazın dikkate alındığında, akıllı cep telefonlarının problemli kullanımlarının sadece bireysel anlamda zararlara değil aynı zamanda akademik anlamda, aile yaşamı anlamında ve toplumsal anlamda birçok olumsuz sonuçlara neden olduğu görülmektedir. İlgili alanyazında araştırmacılar tarafından akıllı cep telefonlarının problemli kullanımına 
ilişkin olarak azaltıcı veya önleyici birtakım programların yapılmasının önerildiği görülmektedir (Lian ve You, 2017; Tao vd., 2017). Alanyazın incelendiğinde ise akıllı cep telefonlarının problemli kullanımlarına ilişkin çok az sayıda deneysel çalışmanın hazırlanıp uygulandığı görülmektedir (Choi, 2015; Choi, Jang ve Lee, 2017; Lee, Seo ve Choi, 2016; Shin ve Jang, 2016; Yu ve Son, 2016). Türkiye' de ise bu konuda herhangi bir deneysel çalışmaya rastlanılmamıştır. Bu bağlamda akıllı cep telefonlarını problemli olarak kullanan ergenler için problemli kullanımlarını azaltmaya yönelik bir psikoeğitim programının hazırlanıp uygulanmasının önemli olduğu düşünülmektedir. Böyle bir çalışmanın hem ilgili alanyazına hem de akıllı cep telefonlarını problemli kullanan ergenlere bu bağlamda katkı sağlayacağı düşünülmektedir.

\section{Yöntem}

$\mathrm{Bu}$ bölümde; araştırmanın modeline, evren ve örnekleme, verilerin toplanmasına, verilerin analizine, araştırma sürecine, deney öncesi yapılan işlemlere, oturumların hazırlanmasına ve grup üyelerinin belirlenmesine ilişkin bilgilere yer verilmiştir.

\section{Araştırmanın Modeli}

Ortaögretime devam eden ergenlerde akıllı cep telefonunun problemli kullanımını azaltmaya yönelik olarak geliştirilen psikoeğitim programının etkililiğinin araştırıldığı bu çalışmada karma yöntem kullanılmıştır. Karma yöntem araştırma, amaçların genişlemesi, derin bir anlayış ve doğrulama adına bir araştırmacının veya araştırmacı grubun nitel ve nicel yaklaşımların unsurlarının birleştirildiği bir araştırma türüdür (Johnson, Onwuegbuzie ve Turner, 2007). Bu araştırmada Şekil 1'de görüldügü üzere karma yöntem araştırma türlerinden olan iç içe karma desen kullanılmıştır. 


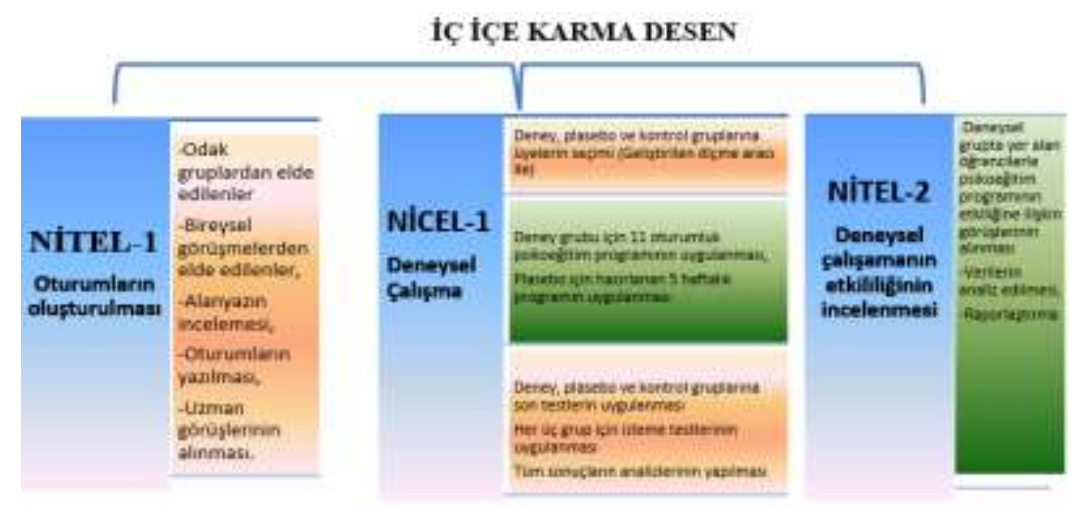

Şekil 1. İç içe Karma Desen

Araştırmanın iç içe karma desen kısmının ilk aşaması olan nitel kısımda fenomenolojik yaklaşım kullanılmıştır. Fenomenolojik (olgubilim) yaklaşım, "farkında olduğumuz ancak derinlemesine ve ayrıntılı bir anlayışa sahip olmadığımız olgulara odaklanmaktadır. Bize tümüyle yabancı olmayan aynı zamanda da tam anlamını kavrayamadı̆̆ımız olguları araştırmayı amaçlayan çalışmalar için olgubilim (fenomenoloji) uygun bir araştırma zemini oluşturur" (Yıldırım ve Şimşek, 2008). Bu bağlamda bu nitel aşamada, ergenlerde akıllı cep telefonunun problemli kullanımını derinlemesine incelemek adına ergenlerle odak grup görüşmeleri, veli ve rehber öğretmenlerle ise bireysel görüşmeler yapılmıştır.

Şekil 1'de görüldüğü üzere ergenlerde akıllı cep telefonunun problemli kullanımını azaltmaya yönelik 11 oturumluk psikoeğitim programının hazırlanmasını, uygulanmasını ve programın etkililiğini test etmek amacıyla nitel ve nicel araştırma yöntemleri bir arada veya art arda kullanılabilen iç içe karma desen yer almaktadır (Creswell ve Plano-Clark, 2015). Literatürde en yaygın iç içe desen tipinin, araştırmacının nitel verileri deneysel desenlerin içine yerleştirmesiyle ortaya çıkan tipidir (Creswell ve Plano-Clark, 2015). Bu araştırmadaki deneysel çalışma kısmında, psikoeğitim programının oturumların hazırlanmasında, iç içe karma desenin ilk aşaması olan nitel aşamada elde edilen verilerden yararlanılmıştır. 11 oturumluk psikoeğitim programının ergenlerde akıllı cep telefonunun problemli kullanımını azaltmadaki etkililiğini test amacıyla 3x3'lük (deney, kontrol ve plasebo X öntestsontest-izleme testi) split plot faktöryel desen kullanılmıştır. Araştırmanın 
son kısmında ise deney grubuna psikoeğitim programının etkililiğine ilişkin görüşlerini içeren nitel veriler elde edilmiştir.

\section{Katılımcilar}

Araştırma üç aşamalı olup birinci aşamada (nitel) odak grup görüşmesi için çalışma gruplarını Elazı ̆̆'da ortaöğretime devam eden öğrencilerden oluşan, her biri altı üyeden oluşan üç farklı odak grup oluşturmaktadır. Bu üç gruba üye seçiminde, "temel anlayışı önceden belirlenmiş bir dizi ölçütü karşılayan bütün durumların çalışılması olan" (Yıldırım ve Şimşek, 2008) ölçüt örnekleme yöntemi kullanılmıştır. Buna göre gruba üye olabilmek için "Problemli Cep Telefonu Kullanım Ölçeği"nden (PCTKÖ) (Güzeller ve Coşguner, 2012) ortalama +1 standart sapma üstünde puana sahip olma, veli izni olması ve gönüllü olma ölçütleri dikkate alınmıştır. İlk aşamada yer alan diğer grup ise bireysel görüşmeler yapıldığı, beş kişiden oluşan öğrenci velileridir. Veliler seçilirken de ölçüt örnekleme kullanılmıştır. Buna göre velilerin seçiminde velilerin çocukları CTPKÖ'den ortalama +1 standart sapma üstünde puana sahip olması, velinin gönüllü olması ölçütleri dikkate alınmıştır. İlk aşamada bireysel görüşme yapılan diğer altı kişilik grup ise rehber öğretmenlerdir. Rehber öğretmenlerin seçiminde ise "araştırmacının problemine ilişkin olarak zengin bilgi kaynağı olabilecek birey veya durumların saptanmasında etkili olan" (Yıldırım ve Şimşek, 2008) kartopu örnekleme yöntemi kullanılmıştır. Buna göre bireysel görüşme yapılan rehber öğretmenler, akıllı cep telefonunun problemli kullanımı konusunda bilgi ve tecrübelerini paylaşabilecek diğer rehber öğretmenlere yönlendirmesiyle altı rehber öğretmenle bireysel görüşme yapılmıştır.

Araştırmanın ikinci aşaması olan deneysel aşamada ise deneysel çalışmada oluşturulan gruplara üye seçimi için 112'si erkek, 121'i kız olmak üzere toplamda 233 kişiden veri toplanmıştır. Belirlenen ölçütleri karşılayan 45 öğrenciden deney, plasebo ve kontrol gruplarına onar üye olacak şekilde 30 (22'si kız, 8'i erkek) öğrenci seçilmiştir. Araştırmanın son aşamasının katılımcıları ise deney grubundaki 10 kişi ( $\left(8^{\prime} \mathrm{i}\right.$ kız, 2'si erkek) oluşturmaktadır.

\section{Verilerin Toplanması}

Araştırmada odak grup görüşmelerinin öğrenci üyelerini belirlemek için 
Güzeller ve Coşguner (2012) tarafından geliştirilen "Problemli Cep Telefonu Kullanım Ölçeği” (PCTKÖ) ile araştırmanın ikinci aşaması olan deney, kontrol ve plasebo gruplarının seçiminde ve programın etkililiğinin değerlendirilmesinde, tez çalışmasının ilk aşamasında keşfedici karma desene dayalı olarak (Pamuk, 2017) ergenler için geliştirilen "Akıllı Cep Telefonlarının Problemli Kullanım Ölçeği” (ACTPKÖ) kullanılmıştır.

Problemli Cep Telefonu Kullanım Ölçeği (PCTKÖ): Güzeller ve Coşguner (2012) tarafından ergenler için geliştirilmiştir. PCTKÖ, varimax döndürme sonucunda varyansın \%55,5'ini açıklayan, 18 madde, üç alt boyuttan (Olumsuz Etkiler, Kompülsiyon/Süreklilik ve Yoksunluk/Tolerans Geliştirme) oluşan, 1 (asla) ile 5 (daima) arasında beşli Likert tipinde ölçüm veren bir ölçme aracı olduğu bulunmuştur. Buna ek olarak, ölçeğe ilişkin yapılan DFA sonuçları şu şekildedir: $X^{2}=477.23, S d=126, X^{2} / S d=3.78$, GFI=0.97, AGFI $=0.90, \mathrm{NFI}=0.95, \mathrm{TLI}=0.96, \mathrm{CFI}=0.97$, RMSEA $=0.066$ ve $\mathrm{SRMR}=0.052$. Ölçeğin güvenirliğine ilişkin olarak Cronbach Alpha iç tutarlık katsayısı Olumsuz Etkiler için .83, Kompülsiyon/Süreklilik için .77 ve Yoksunluk/Tolerans Geliştirme için ise .76 olarak bulunmuştur.

\section{Akıllı Cep Telefonlarının Problemli Kullanım Ölçeği (АСТРКÖ) : АСТРКÖ} Pamuk (2017) tarafından ergenler için geliştirilmiştir. Ölçek açıklanan toplam varyansın \%65.444'nü açılayan, altı boyuttan oluşan (kontrolde başarısızlık, çatışma, yoksunluk, akademik görevlerde sorunlar, gündelik olumsuz sonuçlar ve okulda yaşanan sorunlar), 5'li Likert tipinde ("Hiç uygun değil", "Nadiren uygun", "Biraz uygun", "Oldukça uygun" ve "Tamamen uygun) ölçüm veren bir ölçme aracıdır. Ölçeğin altı faktörlü yapısı için yapılan doğrulayıcı faktör analizi (DFA) sonuçlarına göre $X^{2}=215.652, S d=135$, $X^{2} / S d=1.597, \mathrm{GFI}=0.93, \mathrm{AGFI}=0.90, \mathrm{TLI}=0.93, \mathrm{CFI}=0.95, \mathrm{RMSEA}=0.045$ ve $\mathrm{SRMR}=0.0514$ olarak bulunmuştur. İkinci düzey DFA sonuçları ise şu şekildedir: $X^{2}=239.951, \mathrm{Sd}=144, X^{2} / \mathrm{Sd}=1.666$, GFI=0.92, $\mathrm{AGFI}=0.89, \mathrm{TLI}=0.93$, $\mathrm{CFI}=0.94$, RMSEA $=0.048$ ve $\mathrm{SRMR}=0.0585$. ACTPKÖ'nün güvenirliğine ilişkin sonuçlar incelendiğinde, Cronbach Alpha katsayıları ölçeğin toplamı için .87; kontrolde başarısızlık (KB) alt boyutu için .80; çatışma (ÇA) alt boyutu için .78; yoksunluk (YOK) alt boyutu için .77; akademik görevlerde sorunlar (AGS) alt boyutu için .70; gündelik olumsuz sonuçlar (GOS) alt 
boyutu için .71; okulda yaşanan sorunlar (OYS) alt boyutu için .70 bulunmuştur. Test tekrar test sonuçlarına bakıldığında ise ölçeğin toplamı için .95; $\mathrm{KB}$ alt boyutu için .86; ÇA alt boyutu için .92; YOK alt boyutu için .91; AGS alt boyutu için .87; GOS alt boyutu için .82 ve OYS alt boyutu için .87 bulunmuştur.

\section{Verilerin Analizi}

Araştırmanın farklı aşamalarında nitel ve nicel analiz teknikleri kullanılmıştır. Araştırmanın ilk aşamasında yer alan odak grup görüşmesinden ve son aşamasında yer alan psikoeğitim grubunun etkililiğine ilişkin elde edilen veriler İçerik Analizi ile analiz edilmiştir. Araştırmanın ikinci aşamasında ise nicel analiz teknikleri kullanılmıştır. Araştırmanın ikinci aşamasını oluşturan deneysel çalışma kısmında Kruskal Wallis H Testi, Mann Whitney U Testi, Friedman Mertebeler Testi ve İkili Karşılaştırmalara Dayalı Wilcoxon İşaretli Sıralar Testi kullanılmıştır. Verilerin analizinde SPSS 22 programı kullanılmıştır.

\section{Süreç}

Araştırmanın ilk aşamasına başlamadan önce uygulamalar için ilk olarak İnönü Üniversitesi Sosyal ve Beşeri Bilimler Bilimsel Araştırma ve Yayın Etiği Kurulu Etik Kurul'undan etik izni alınmıştır. Daha sonrasında Elazığ İl Milli Eğitim Müdürlüğü'nden uygulama izni alınmıştır. Ayrıca uygulama yapılan okul idaresi'nden de olur izni alınarak uygulamaya geçilmiştir. Uygulamanın ilk aşamasında akıllı cep telefonunun problemli kullanımına ilişkin görüşler almak üzere ergenlerle, velilerle ve rehber öğretmenlerle görüşmeler yapılmıştır. Bu süreçte tüm katılımcılara, görüşmelere ilişkin kayıtların gizli kalacağı ve isimlerinin hiçbir şekilde raporlaştırma aşamasında kullanılmayacağ belirtilmiştir.

Araştırmanın ikinci aşaması olan deneysel uygulamanın olduğu aşama bahar dönemine rastladığından uygulamalar için Elazı̆̆ Milli Eğitim Müdürlüğü'nden (MEM) yeniden izin alınmıştır. Deneysel aşamaya ilişkin süreç üç aşamada belirtilmiştir: Deney öncesi yapılan işlemler, deney sırasında ve deneyden sonra yapilan işlemler. 


\section{Deney Öncesi Yapılan İşlemler}

Deneysel çalışmada uygulamaya başlamadan önce alanyazının yanında ergenlerle yapılan odak görüşmeler, veli ve rehber öğretmenlerle yapılan bireysel görüşmeler dikkate alınarak ergenler için ergenlerde "Akıllı Cep Telefonunun Problemli Kullanımını Azaltmaya Yönelik Bir Psikoeğitim Programı"adıyla bir psikoeğitim programı geliştirilmiştir.

Aşağıda deney grubu için "Akıllı Cep Telefonunun Problemli Kullanımını Azaltmaya Yönelik Bir Psikoeğitim Programı"nın ve Plasebo grubu için de "Verimli Ders Çalışma Programı"nın hazırlanma süreçleri ile deneysel çalışmada yer alacak gruplara (deney, plasebo ve kontrol) üye belirlemek adına yapılan işlemlere yer verilmiştir.

\section{Oturumların Hazırlanması}

Bu kısımda hem deney grubu hem de plasebo grubu için hazırlanan oturumların hazırlanılışları konusunda açıklamalara yer verilmiştir.

Deney grubunun oturumlarıın hazırlanması: "Akıllı Cep Telefonunun Problemli Kullanımını Azaltmaya Yönelik Psikoeğitim Programı" hazırlanırken öncelikle alanyazın incelenmiştir. Ancak akıllı cep telefonunun problemli kullanımına ilişkin yapılan neredeyse yok denilecek kadar az sayıda deneysel çalışmaya rastlanılmıştır (Choi, 2015; Choi, Jang ve Lee, 2017; Lee, Seo ve Choi, 2016; Shin ve Jang, 2016; Yu ve Son, 2016). Bu durum da dikkate alınarak, araştırmada daha yeni bir kavram olan "akıllı cep telefonunun problemli kullanımı" kavramını daha iyi irdelemek için ergenler, veliler ve rehber öğretmenlerle yarı yapılandırılmış görüşmeler yapılmıştır. Bu yarı yapılandırılmış görüşmelerde kavramın yanı sıra bu problemli duruma etki eden faktörlerle problemli kullanımın sebep olduğu sonuçlar da belirlenmeye çalışılmıştır. Bu çalışmalar, bir çeşit psikoeğitim programı oluşturulması öncesinde ihtiyaç analizi niteliğinde olmuştur. Yapılan görüşmeler sonucunda akıllı cep telefonunun problemli kullanımı genel kanı olarak ergenlerce bir problem olarak görülmediği, bu probleme ilişkin farkındalık oluşturmaya ihtiyaç duyulduğu, aile faktörünün önemli bir faktör olduğu, bu problemin ergenlerin yaşamlarını birçok 
alanda olumsuz etkilediği, akıllı cep telefonlarının kullanımına ilişkin özkontrol becerilerinin düşük olduğu, zamanın verimsiz kullanılmasına neden olduğu gibi faktörler ortaya çıkmıştır. Bu faktörlerin ergenlerde akıllı cep telefonunun problemli kullanımında rol oynadığı belirlenmiştir. Görüşmeler sonucu ortaya çıkan faktörler dikkate alınarak psikoeğitim programının hazırlanmasında bu faktörlere olanaklar ölçüsünde yer verilmeye çalışılmıştır. Bu bağlamda görüşmelerde ortaya çıkan kimi faktörlerin oturumlara yerleştirilmesi mümkünken kimi faktörler için bu durum geçerli olamamıştır. Örneğin, ailelerin cep telefonlarını kullanımı konusunda kötü rol model olmalarına ilişkin oturumlara herhangi bir şey yerleştirilememiş çünkü araştırma kapsamında ebeveynler psikoeğitim kapsamında yer almamışlardır; ancak akıllı cep telefonunun problemli kullanımına bağlı ebeveyn-ergen çatışmasını ele alan, odak grup görüşmelerinden anlatılanlardan esinlenerek hazırlanan senaryo rol yapma tekniğiyle oynanacak şekilde oturumlara yerleştirilmiştir. Oturumlar hazırlanırken, yapılan görüşmeler, konuyla ilişkili önceden uygulanmış deneysel çalışmalar ile Erkan ve Kaya (2005; 2009; 2015a; 2015b) editörlügüünde hazırlanan, daha önceden ise lisansüstü tezler olarak sunulan tezlerin yer aldığı kitaplardaki lisansüstü çalışmalar incelenmiştir.

“Akıllı Cep Telefonunun Problemli Kullanımını Azaltmaya Yönelik Psikoeğitim Programı"'nda amaçlanan, ergenlerin akıllı cep telefonlarını ihtiyacı kadar kullanabilme becerisini kazanması ve işlevsel kullanıcılar haline gelmelerine yardımcı olmaktır. Bu amaç ve belirlenen ihtiyaçlar doğrultusunda hazırlanan programın etkili olacağı düşünülmüştür. Bu süreçte, deney grubunu oluşturan üyelerle yaklaşık olarak ortalama 60-75 dakika sürecek ve 11 oturumdan oluşan psikoeğitim programı hazırlanmıştır. Oturumlar her hafta bir kere olacak şekilde düşünülmekle beraber bazı haftalarda sınav vakitleri dikkate alınarak bir haftada iki oturum yapılması planlanmıştır. Hem deney grubunun hem de plasebo grubunun oturumları araştırmacının bizzat kendisi tarafından yürütülmüştür.

Akıllı cep telefonunun problemli kullanımını azaltmaya yönelik psikoeğitim programı; akıllı cep telefonunun problemli kullanımına ilişkin ortaya çıan bilimsel kanıtlara dayalı sonuçları görebilme, katılımcların akıllı cep telefonlarını aşırı ve gereğinden fazla kullanmalarının olumsuz etkilerine ilişkin etkinlikleri yaparak farkındalık oluşturma, akıllı cep telefonlarını yoğun olarak kullanmayı düşündükleri 
anların farkına varıp bunlarla mücadele etmede kullanacakları bir nevi kendi kendilerine verecekleri komut cümlelerini oluşturma, akıllı cep telefonlarını aşırı ve gereğinden fazla kullanmadan dolayı yaşamlarında erteledikleri veya yapmadıkları aktivitelerin farkına varma, bu ertelediği aktiviteleri yapmaya yönelik ev ödevi olarak eylemde bulunma, akıllı cep telefonlarını aşırı ve gereğinden fazla kullanmadan dolayı aile içi ve okul yaşamında ortaya çıkan çatışmaların farkına varma ve karşı tarafların yaşadığı duyguları tecrübe etme bağlamında rol yapma, günlük yaşamda karşılaştıkları problemleri çözme yerinin cep telefonları değil, gerçek yaşam olduğunu anlamaya yönelik rol yapma, akıllı cep telefonlarını kullanırken yaşadıkları kontrol güçlüğünün farkına varmaları, bu kontrol güçlüğüyle baş etme bağlaminda eylemde bulunma, akıllı cep telefonlarını gerek olmadığı müddetçe kullanmalarının uygun olmadığı yerleri tespit edip farkına varma ve bununla baş etmek için eylemde bulunma, akıllı cep telefonlarını rutin bir hafta içi ve hafta sonu gününde ne vakitlerde yoğun kullandıklarını belirleyip bu yoğun vakitleri başka vakitlere kayırma adına plan yapıp gerçek yaşamda uygulama yapma ve cep telefonlarını gizli ve saklı kullanmalarının zararlarının farkına varma gibi birtakım hedefleri içermektedir.

Yukarıda belirtilen hedefler kısaca ifade edilecek olursa, bu program hazırlanırken ergenlerde farkındalık oluşturmaya, bakış açılarını değiştirmeye, günlük yaşamdaki olumsuz etkilerini görmelerine yardımcı olmaya, işlevsel kullanıcı olmaları konusunda cesaretlendirmeye, zaman yönetimine ve öz-kontrol becerisi geliştirmeye odaklanılmıştır. Oturumlar oluşturulurken bazı bilişsel davranışçı tekniklerinden esinlenilmiştir. Hazırlanan her bir oturuma ilişkin içerik kısaca şu şekildedir:

- Oturum 1: İlk oturumda tanışma yapıldıktan sonra lider tarafından grubun genel amaçları grup üyelerine dağıtılmış, üzerinde konuşulduktan sonra ekleme yapmak isteyen üye olup olmadığ sorulduktan sonra herkesin genel amaçlar hususunda hemfikir oldukları görülmüş̧ür. Daha sonra üyelerden lider tarafından kendilerine verilen bireysel amaç formlarına bireysel amaçlarını yazmaları istenmiş ve yazdıktan sonra tüm üyelerden her iki formu da imzalamaları istenmiş ve özetleme yapılarak oturum sonlandırılmıştır. 
- Oturum 2: Bu oturumda grup üyelerine akıllı cep telefonlarının aşırı, gereğinden fazla, problemli kullanımının insan yaşamındaki ortaya çıkardığı olumsuz sonuçlarını Türkiye ve dünya literatürüne dayanarak hazırlanan etkinlikler aracığıyla kanıta dayalı bir biçimde sunmak ve üyelerin kendi yaşamlarında da benzer sonuçları görmeleri amaçlanmıştır.

- Oturum 3: Bu oturumda ergenlerin akıllı cep telefonlarını hangi durum ve anlarda yoğun şekilde düşündüklerini tespit etme ve bu yoğun düşünme sebebiyle normalde yapması gerekip yapmadığ veya ertelediği görev ve sorumluluklarının farkına varıp bu durumun yaşamlarında ortaya çıkardığı olumsuz sonuçları yazarak dile getirmeleri ve üzerinde tartışmaları amaçlanmıştır. Oturumda diğer yapılan etkinlik ise ergenlerin yoğun düşünme geldiğinde kendilerine komut şeklinde olabilecek bu düşüncelerle mücadele etmede kullanabilecekleri, kendilerine özgü slogan cümleler oluşturmaları istenmiştir ve bunları kullanmaları istenmiştir.

- Oturum 4: Dördüncü oturuma bir önceki oturumun kısa bir özetlemesi yapılarak başlanmıştır. Bu oturumda, grup üyelerinin akıllı cep telefonlarını kullanmak adına sosyal yaşamlarında katılmadıkları veya erteledikleri etkinliklere (arkadaşlarıyla beraber bir yerlere gitme, akşamları aileleriyle beraber oturma, piknik, sinema, akraba ziyaretleri, vb...) ilişkin olarak, üyelerde bu durumların nedenlerini irdeleyelerek farkındalık oluşturma ve bu durumlara ilişkin eylemde bulunma amaçlanmıştır.

- Oturum 5: Bu oturumda akıllı cep telefonlarını aşırı ve gereğinden fazla kullanmanın çevresindeki bazı kişilerle sorun yaşamasına neden olduğunu farkedebilme, sorun yaşadığı kişilerin yerine kendini koyabilme becerisine sahip olabilme ve bu gibi durumlara ilişkin olarak çatışmalarda etkin çözüm üretebilme becerisini, yapılan odak grup ve bireysel görüşmelerden esinlenerek hazırlanmış olan anne-çocuk, baba-çocuk ve öğretmen-çocuk şeklinde senaryoların oynanması üzerinden kazandırmak amaçlanmıştır. 
- Oturum 6: Bu oturumda günlük yaşamda karşılaşılan bazı problemlerden kaçmak veya rahatlamak adına akıllı cep telefonlarıyla çok fazla zaman harcamak yerine, gerçek yaşamda sorunlarla yüzleşerek onlara çözüm üretebilme üzerine rol oynama yapılarak iki senaryonun oynanarak farkındalık oluşturmaya çalışılmıştır. Bunun yanında grup üyelerinin günlük yaşamda karşılaştığı problemler (üzüntü, kaygı, depresyon, öfke, stres, can sıkıntısı gibi) karşısında akıllı cep telefonlarını kullanarak rahatlamaya çalıştıkları anları hatırlayarak yazmaları istenen formlar vermiştir. "Bu şekilde cep telefonuyla uğraşmak yerine gerçekçi, etkili çözüm üretsen sence bu çözüm ne olurdu?" sorusuna cevaplar yazmaları istenmiştir. Lider her üyeye dönütler vererek hem üye hem de grup açısından farkındalık oluşturmayı amaçlamıştır.

- Oturum 7: Bu oturumda grup üyelerine akıllı cep telefonlarını kullanımına ilişkin olarak hangi durum ve anlarda kontrol etmede güçlük çektiğine ilişkin farkındalık kazandırmanın yanısıra akıllı cep telefonlarını kullanmaya ilişkin öz kontrol becerileri geliştirmenin öneminin farkına varma ve telefon kullanımlarını takip etme amaçlarına yönelik etkinlikler yapılmıştır. Öz kontrol becerisi kazanmaları için telefonlarına güvenirliği önceden araştırılmış programlar kurmaları sağlanmış ve kendi kullanımlarını net bir biçimde görmeleri sağlanmaya çalışılmıştır.

- Oturum 8: Bu oturumda grup üyelerinin akıllı cep telefonlarını kullanırken yaşadıkları kontrol güçlüklerinin farkına varabilmeleri, akıllı cep telefonların kullanmamaya özen göstermeleri gereken yerleri tespit edebilme ve bu yerlerde kullanmanın zararlarını farkedebilmelerinin yanında eylem olarak da gereksiz uygulamaları silmeleri ve kendilerine kullanım sınır koymaları amaçlanmıştır.

- Oturum 9: Bu oturumda akıllı cep telefonunun rutin bir hafta içi ve sonu kullanımlarının yoğunluğunu ve bu yoğunlukta yapılan işleri belirleyebilmenin yanında bu yoğun kullanımın olduğu vakitleri, telefonla olan meşguliyeti azaltacak başka vakitlere kayırma yaparak 
üyelerce kendileri için yeni hafta içi ve hafta sonu program oluşturulması amaç edinilmiştir.

- Oturum 10: Bu oturumda akillı cep telefonunun gizli ve saklı kullanımının olumsuz sonuçlarını içeren, önceden hazırlanmış senaryonun üyelerce oynanmasıyla hem role giren üyelerde hem de diğer grup üyelerinde farkındalık oluşturulması amaçlanmıştır.

- Oturum 11: Bu oturumda lider üyelere önceki oturumlardan kısaca bahsettikten sonra üyelerden nasıl bir yaşantı geçirdiklerini paylaşmalarını istemiştir. Üyeler aynı zamanda bu psikoeğitim aracılığıyla nelerin değiştiğinden, neler kazandıklarından bahsetmişlerdir. Lider her bir üyenin yaşantılarına ilişkin gözlemlerini de katarak dönüt vermiştir. İkramlardan sonra süreç sonlandırılmıştır.

\section{Plasebo Grubunun Oturumlarının Hazırlanılması}

Plasebo grubu için hazırlanan oturumlar, haftada bir kez olacak biçimde beş haftalık bir sürece yayılmış beş oturumluk bir grup rehberlik programı olarak hazırlanmıştır. Oturumlar 35-40 dakika şeklinde kısa süreli olarak gerçekleştirilmiştir. Bu beş oturumluk grup rehberliği çalışmasında öğrencilere verimli ders çalışma üzerine bilgiler aktarılmıştır. Oturumlarda rol oynama veya herhangi özel bir teknik uygulanmamıştır. Oturumlarda teknolojinin, özellikle de akıllı telefonların ders çalışma üzerindeki etkilerine girilmemiştir. Hazırlanan beş oturumun içeriği ise şu şekildedir:

- Oturum 1: Bu oturumun başında öncelikle grup üyeleriyle tanışma yapılmıştır. Ardından grup üyelerinden sırasıyla "Ders, Ders Çalışma, Hazırbulunuşluk ve Verimli Ders Çalışma" kavramları hakkında neler düşündüklerini gruba aktarmaları istenmiştir.

- Oturum 2: Bu oturumda ise önceki oturum kısaca özetlendikten sonra grup üyelerinden hedef-amaç kavramları hakkında neler düşündüklerini ifade etmeleri ve verilen formlara hedeflerini yazmaları istenmiştir. 
- Oturum 3: Bu oturumda grup üyelerinden öğrenme kavramı hakkında görüşlerini gruba açıklamaları istenmiştir. Ardından öğrencilere öğrenme stilleri testi verilmiştir. Grup üyelerine öğrenme stilleri üzerine bilgi verilmiştir.

- Oturum 4: Bu oturumda üyelere sirasiyla etkin dinleme (İFIKAN) ve etkin okuma (ISOAT) metotları hakkında bilgi olan formlar verilmiş ve her iki form üzerinde grup üyeleriyle konuşulmuştur.

- Oturum 5: Bu oturumda üyelere zamanin öneminden bahseden sözlerden oluşan form dağıtılmış ve her bir söz üzerine grup üyelerinden fikir beyan etmeleri istenmiştir.

\section{Grup Üyelerinin Belirlenmesi}

$\mathrm{Bu}$ çalışmada grup üyelerinin belirlenmesinde bazı kriterler dikkate alınmıştır. Sınıf düzeyi olarak 10. sınıflar seçilmiştir. Bu seçimin yapılmasında, 12. sınıfların üniversiteye giriş için gerekli olan sınavlara hazırlanıyor olmaları, dokuzuncu sınıfların ise ortaöğretime yeni başlamış olmalarından kaynaklı uyum sorunlarının olabilmesi, 11. sınıflar için ise üniversite sınavlarının hemen öncesinde olması gibi bazı nedenler etkili olmuştur. Bu bağlamda okulun 10. sınıf öğrencilerinden veriler toplanmıştır. Veriler toplanmadan önce ise Elazı̆̆ Milli Eğitim Müdürlüğ̈̈'nden gerekli izinler alınmış, alınan izinler okul yönetimiyle paylaşılarak gerekli izinler sağlanmıştır. Araştırmada uygulamanın yapılma amacı öğrencilere açıklanmış ve geliştirilen ölçme aracı araştırmacı tarafından öğrencilere uygulanmıştır. Veri toplama aracına uygulamadan sonraki aşamada yer alan deneysel çalışma aşamasına gönüllü katılımcı olup olmayacakların belirtmeleri istenmiştir. Uygulama sonucunda ortalaması 49,1 standart sapması 19,2 olmak üzere 112'si erkek, 121'i kız olmak üzere toplamda 233 kişiden veri toplanmıştır. Katılımcıların gruplara alınmasında üç koşul aranmıştır: 1. Ort +1Ss puan ve üzeri olması, 2. Katılımcının gönüllü olması, 3. Katılımcının veli izninin olmasi. 
Tablo 1. Deneysel Çalışmadaki Gruplar İçin Üye Belirlemek Adına Toplanan Verilerin Betimsel İstatistikleri

\begin{tabular}{lcccccc}
\hline & & n & En düşük & En yüksek & Ort. & Std. Sapma \\
\hline Erkek & АCTPKÖ & 112 & 19 & 84 & 44,7 & 17,6 \\
Kı1z & АСТРКÖ & 121 & 19 & 88 & 53,3 & 19,7 \\
Toplam & ACTPKÖ & 233 & 19 & 88 & 49,1 & 19,2 \\
\hline
\end{tabular}

Deneysel grupları belirlemek için yapılan veri toplama işlemi sonucunda ortalama +1 standart sapma ve üzeri puana sahip olan 57 öğrenci belirlenmiştir. Bu öğrencilerden 8 tanesinin gönüllü olmadığı, 4 'ünün ise veli izninin olumsuz olması nedeniyle istenen üç şartı sağlayan 11'i erkek 34 'ü kız olmak üzere 45 öğrenci kalmıştır. Gerekli şartları taşıyan katılımcların seçimi için her gruba onar katılımcı olacak şekilde kura çekilmiştir. Bu şekilde deney, plasebo ve kontrol grupları oluşturulmuştur.

\section{Bulgular}

\section{Deneysel Çalışmaya İlişkin Süreç Ve Bulgular}

Bu kısımda, yöntem kısmında seçim süreçleri ayrıntılı bir şekilde anlatılan grup üyelerine ait betimsel istatistiksel bulgular, grupların deneysel çalışma öncesi birbirlerine denk olup olmadığına ilişkin istatistiki bulguların yanısıra deney öncesi uygulanan ön testler ile deney sonrası uygulanan son test ile izleme testlerinin her grubun hem kendi içinde hem de diğer gruplarla karşılaştırılmalarına dayalı istatistiki sonuçlar yer almaktadır.

Tablo 2. Deney, Plasebo ve Kontrol Gruplarının ACTPKÖ Öntest Puanlarına İlişkin Betimleyici Istatistikler

\begin{tabular}{cllccc}
\hline & Grup & & $\mathbf{n}$ & Ortalama & Standart Sapma \\
\hline & & Kiz & 8 & 84.1 & 2.9 \\
& \multirow{2}{*}{ Deney } & Erkek & 2 & 83.5 & .70 \\
& & Toplam & 10 & 84.0 & 2.7 \\
\cline { 3 - 6 } & & Kiz & 7 & 82.5 & 1.5 \\
& & Erkek & 3 & 80.0 & 1 \\
& & Toplam & 10 & 81.8 & 1.8 \\
\hline \multirow{2}{*}{ Kontrol } & Kiz & 7 & 82.7 & 1.8 \\
& & Erkek & 3 & 82.7 & 1.5 \\
& & Toplam & 10 & 82.7 & 1.6 \\
\hline
\end{tabular}


Tablo 2 incelendiğinde, deney, plasebo ve deney gruplarının АCTPKÖ'ye ilişkin ortalama ve standart sapma puanları verilmiştir. Deneysel çalışmalara geçmeden önce her üç grubun ortalama puanlarının homojen olup olmadığını belirlemek adına sayının az olması da dikkate alınarak nonparametrik testlerden Kruskall Wallis $\mathrm{H}$ testi ile uygulanmıştır.

Tablo 3. Deney, Plasebo ve Kontrol Grubu Üyelerinin ACTPKÖ Öntest Puanlarna İlişkin Kruskal Wallis H Testi Sonuçları

\begin{tabular}{cccccc}
\hline & & $\mathbf{n}$ & Sira Ortalamas1 & $\mathbf{X}^{2}$ & p \\
\hline \multirow{2}{*}{$: 0$} & Deney & 10 & 19.6 & & \\
Plasebo & 10 & 11.5 & 4.319 & .115 \\
& Kontrol & 10 & 15.5 & & \\
\hline
\end{tabular}

Tablo 3'te görüldüğü gibi üç grup arasında ACTPKÖ öntest puanları arasında anlamlı bir fark olmadığı görülmektedir $\left(X^{2}=4.319, \mathrm{Sd}=2\right.$, $\mathrm{n}=10, \mathrm{p}>$. 05). Bu sonuca göre, üç grubun puan ortalamaları bakımından birbirine denk olduğu görülmektedir.

Tablo 4. Deney Grubunun ACTPКÖ'ye İlişkin Öntest, Sontest ve İzleme Testlerine İlişkin Friedman Mertebeler Testi Sonuçları

\begin{tabular}{lcccc}
\hline Ölçümler & $\mathbf{n}$ & Sıra Ortalaması & Sd & $\mathbf{X}^{2}$ \\
\hline Öntest & 10 & 3 & & \\
Son test & 10 & 1.30 & 2 & $15.8^{*}$ \\
İzleme testi & 10 & 1.70 & & \\
\hline
\end{tabular}

${ }^{*} \mathrm{p}<.001$

Tablo 4'te görüldüğü gibi Friedman Mertebeler Testi ile yapılan analizde, deney grubu öğrencilerinin АCTPKÖ'ye ilişkin öntest, sontest ve izleme ölçümleri arasında istatistiksel olarak anlamlı bir fark olduğu ortaya çıkmıştır ( $\left.X^{2}=15.8 ; \mathrm{p}<.001\right)$. Bu farkı belirlemek amacıyla ikili gruplar, Wilcoxon İşaretli Sıralar Testi ile karşılaştırılmış ve elde edilen sonuçlar Tablo 5 'te gösterilmiştir.

Tablo 5 incelendiğinde, deney grubunun ACTPKÖ öntest puanları ile ACTPKÖ sontest puanları arasında anlamlı bir fark olduğu bulunmuştur $(\mathrm{z}=-2,818 ; \quad \mathrm{p}<.05)$. Fark puanlarının sira ortalaması ve sıra toplamları dikkate alındığında, gözlenen farkın negatif sıralar yani sontest puanları lehine düşük olduğu anlaşılmaktadır. Diğer bir ifade ile sontest puanlarının öntest puanlarına göre anlamlı biçimde daha düşük olduğu görülmektedir. Tablo 
5 'teki diğer bir bulguda, deney grubunun АСТРКÖ öntest puanları ile izleme testi puanları arasında da anlamlı bir fark olduğu bulunmuştur $(\mathrm{z}=-$ $2.821 ; \mathrm{p}<.05)$.

Tablo 5. Deney Grubunun ACTPKÖ'ye İlişkin Öntest, Sontest ve İzleme Ölçümleri İkili Karşılaştırmalarına Dayalı Wilcoxon İşaretli Sıralar Testi Sonuçları.

\begin{tabular}{|c|c|c|c|c|c|}
\hline İkili karşılaştırmlar & & $\mathrm{n}$ & Sira Ortalamas1 & Sira Toplamı & $\mathrm{z}$ \\
\hline & Negatif sıra & 10 & 5.50 & 55 & \\
\hline \multirow[t]{2}{*}{ Sontest-öntest } & Pozitif sıra & 0 & .00 & & $-2.818^{*}$ \\
\hline & Eşit & 0 & & & \\
\hline \multirow{3}{*}{ İzleme-öntest } & Negatif sıra & 10 & 5.50 & 55 & \\
\hline & Pozitif sıra & 0 & & & $-2.821^{*}$ \\
\hline & Eşit & 0 & & & \\
\hline \multirow{3}{*}{ Son test-izleme } & Negatif sıra & 3 & 5.33 & 16 & \\
\hline & Pozitif sıra & 7 & 5.57 & 39 & -1.196 \\
\hline & Eşit & 0 & & & \\
\hline
\end{tabular}

${ }^{*} \mathrm{p}<.05$

Sıra ortalaması ve sıra toplamları dikkate alındığında, gözlenen farkın negatif sıralar lehine düşük olduğunu başka bir deyişle izleme testi puanlarının öntest puanlarına göre anlamlı biçimde daha düşük olduğunu göstermektedir. Son olarak Tablo 5'te yer alan diğer bir bulguya göre sontest puanları ile izleme testi puanları arasında anlamlı bir farkın olmadığı görülmektedir ( $\mathrm{z}=-1.196 ; \mathrm{p}>.05)$. Bu bulgular bir arada değerlendirildiğinde, deney grubunun deney öncesinde sahip oldukları ACTPKÖ puanlarının uygulanan 11 oturumluk psikoeğitim programının sonunda anlamlı biçimde düştüğü ve uygulamanın bitişinden altı hafta sonra izleme ölçümlerinden elde edilen sonuçlarında da bu düşüşün sürdüğü söylenebilir.

Tablo 6. Plasebo Grubunun ACТРКÖ'ye İlişkin Öntest, Sontest ve İzleme Testlerine İlişkin Friedman Mertebeler Testi Sonuçları

\begin{tabular}{llccc}
\hline Ölçümler & $\mathbf{n}$ & Sıra Ortalaması & Sd & $\mathbf{X}^{2}$ \\
\hline Öntest & 10 & 2.45 & & \\
Son test & 10 & 1.85 & 2 & 3.405 \\
İzleme testi & 10 & 1.70 & & \\
\hline
\end{tabular}

Tablo 6'da görüldügü gibi Friedman Mertebeler Testi ile yapılan analizlerde, plasebo grubu öğrencilerinin ACTPKÖ'ye ilişkin öntest, sontest ve izleme ölçümleri arasında istatistiksel olarak anlamlı bir fark olmadığı anlaşılmaktadır ( $\left.X^{2}=3.405 ; \mathrm{p}>.05\right)$. Bu bulgu plasebo grubu ile gerçekleştirilen 
verimli ders çalışmaya ilişkin yapılan programın ACTPKÖ’den alınan puanları düşürmede anlamlı bir etkisinin olmadığını göstermektedir.

Tablo 7. Kontrol Grubunun ACTPKÖ'ye İlişkin Öntest, Sontest ve İzleme Testlerine İlişkin Friedman Mertebeler Testi Sonuçları

\begin{tabular}{lcccc}
\hline Ölçümler & $\mathbf{n}$ & Sira Ortalaması & Sd & $\mathbf{X}^{\mathbf{2}}$ \\
\hline Öntest & 10 & 2.10 & & \\
Son test & 10 & 2.05 & 2 & .389 \\
İzleme testi & 10 & 1.85 & & \\
\hline
\end{tabular}

Tablo 7'de görüldüğü gibi Friedman Mertebeler Testi ile yapılan analizlerde, kontrol grubu öğrencilerinin АCTPKÖ'ye ilişkin öntest, sontest ve izleme ölçümleri arasında istatistiksel olarak anlamlı bir fark olmadığ 1 anlaşılmaktadır ( $\left.\mathrm{X}^{2}=.389 ; \mathrm{p}>.05\right)$.

Tablo 8. Deney, Plasebo ve Kontrol Grubu Üyelerinin ACTPKÖ Sontest Puanlarna İlişkin Kruskal Wallis H Testi Sonuçları

\begin{tabular}{|c|c|c|c|c|c|}
\hline & & $\mathbf{n}$ & Sira Ortalaması & $\mathbf{X}^{2}$ & $\mathrm{p}$ \\
\hline \multirow{3}{*}{ 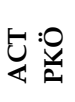 } & Deney & 10 & 5.50 & \multirow{3}{*}{19.505} & \multirow{3}{*}{$.000^{*}$} \\
\hline & Plasebo & 10 & 20.25 & & \\
\hline & Kontrol & 10 & 20.75 & & \\
\hline
\end{tabular}

${ }^{*} \mathrm{p}<.05$

Tablo 8 incelendiğinde, grupların ACTPKÖ'den elde ettikleri sontest puanlarına ilişkin yapılan Kruskal Wallis $\mathrm{H}$ analizine göre, gruplar arasında istatistiksel olarak anlamlı bir fark olduğu görülmektedir $\left(X^{2}=19.505 ; \mathrm{Sd}=2\right.$; $\mathrm{p}<.05)$. Bu farkın hangi grup veya gruplara ilişkin olduğunu belirlemek amacıyla MannWhitney U Testi uygulanmış ve elde edilen sonuçlar Tablo 9'da gösterilmiştir.

Tablo 9. Deney, Plasebo ve Kontrol Gruplarının Sontest Ölçümlerinin İkili Karşılaştırmalarına Dayalı Mann-Whitney U Testi Sonuçları

\begin{tabular}{lccccc}
\hline İkili karşılaştırmalar & $\mathbf{n}$ & Sira Ortalaması & Sira Toplamı & $\mathbf{U}$ & $\mathbf{z}$ \\
\hline \multirow{2}{*}{ Deney-plasebo } & \multirow{2}{*}{10} & $\begin{array}{c}5.50 \\
15.50\end{array}$ & $\begin{array}{c}55 \\
155\end{array}$ & .000 & \multirow{2}{*}{$-3.790^{*}$} \\
\hline \multirow{2}{*}{ Deney-kontrol } & \multirow{2}{*}{10} & $\begin{array}{c}5.50 \\
15.50\end{array}$ & $\begin{array}{c}55 \\
155\end{array}$ & .000 & \multirow{2}{*}{$-3.787^{*}$} \\
\hline \multirow{2}{*}{ Plasebo-kontrol } & \multirow{2}{*}{10} & $\begin{array}{c}10.25 \\
10.75\end{array}$ & $\begin{array}{c}102.5 \\
107.5\end{array}$ & \multirow{2}{*}{47.50} & -.191 \\
\hline
\end{tabular}

${ }^{*} \mathrm{p}<.01$ 
Tablo 9 incelendiğinde, Mann Whitney $U$ testinin sonuçlarına göre, deney grubunun ACTPKÖ son test puanları ile plasebo grubunun $(U=, 000$; $\mathrm{p}<.01)$ ve kontrol grubunun $(\mathrm{U}=, 000 ; \mathrm{p}<.01)$ son test puanları arasinda anlamlı bir fark olduğu bulunmuştur. Sıra ortalamaları ve sıra toplamlarına bakıldığında, deney grubunun ACTPKÖ son test puanlarının plasebo ve kontrol grubunun ACTPKÖ son test puanlarından anlamlı düzeyde düşük olduğu görülmektedir. Plasebo ve kontrol grupları arasında ACTPKÖ son test puanlarında istatistiksel olarak anlamlı bir fark bulunmamıştır. Bu bulgular dikkate alındığında, deney grubuna uygulanan psikoeğitim programının ergenlerin akıllı cep telefonlarını problemli kullanımlarını azaltmada etkili olduğu söylenebilir.

Tablo 10. Deney, Plasebo ve Kontrol Grubu Üyelerinin ACTPKÖ İleme Testleri Puanlarına İlişkin Kruskal Wallis H Testi Sonuçları

\begin{tabular}{cccccc}
\hline & & $\mathbf{n}$ & $\begin{array}{c}\text { Sira } \\
\text { Ortalamas1 }\end{array}$ & $\mathbf{X}^{2}$ & $\mathbf{p}$ \\
\hline \multirow{2}{*}{$: 0$} & Deney & 10 & 5.50 & & \\
Plasebo & 10 & 18.95 & 20.263 & $.000^{*}$ \\
\hline
\end{tabular}

${ }^{*} \mathrm{p}<.05$

Tablo 10'da görüldüğü gibi, grupların ACTPKÖ'den elde ettikleri izleme testi puanlarına ilişkin yapılan Kruskal Wallis $\mathrm{H}$ analizine göre, gruplar arasında istatistiksel olarak anlamlı bir fark olduğu görülmektedir $\left(\mathrm{X}^{2}=20,263\right.$; $\mathrm{Sd}=2 ; \mathrm{p}<.05)$. Bu farkın hangi grup veya gruplara ilişkin olduğunu belirlemek amacıyla MannWhitney U Testi uygulanmış ve elde edilen sonuçlar Tablo 11 'de gösterilmiştir.

Tablo 11. Deney, Plasebo ve Kontrol Gruplarını İzleme Testi Ölçümlerinin İkili Karşılaştırmalarına Dayalı Mann-Whitney U Testi Sonuçlan

\begin{tabular}{lccccc}
\hline İkili karşılaştırmalar & $\mathbf{n}$ & Sıra Ortalaması & Sıra Toplamı & $\mathbf{U}$ & $\mathbf{z}$ \\
\hline \multirow{2}{*}{ Deney-plasebo } & \multirow{2}{*}{10} & $\begin{array}{c}5.50 \\
15.50\end{array}$ & $\begin{array}{c}55 \\
155\end{array}$ & \multirow{2}{*}{.000} & \multirow{2}{*}{$3.792^{*}$} \\
\hline \multirow{2}{*}{ Deney-kontrol } & \multirow{2}{*}{10} & $\begin{array}{c}5.50 \\
15.50\end{array}$ & $\begin{array}{c}55 \\
155\end{array}$ & \multirow{2}{*}{.000} & \multirow{2}{*}{$3.801^{*}$} \\
\hline \multirow{2}{*}{ Plasebo-kontrol } & \multirow{2}{*}{10} & 8.95 & 89.50 & \multirow{2}{*}{34.5} & \multirow{2}{*}{-1.200} \\
\hline
\end{tabular}

${ }^{*} \mathrm{p}<.01$ 
Tablo 11 incelendiğinde, Mann Whitney $U$ testinin sonuçlarına göre, deney grubunun ACTPKÖ izleme testi puanları ile plasebo grubunun $(\mathrm{U}=, 000 ; \mathrm{p}<.01)$ ve kontrol grubunun $(\mathrm{U}=, 000 ; \mathrm{p}<.01)$ izleme testi puanlar1 arasında anlamlı bir fark olduğu bulunmuştur. Sıra ortalamaları ve sıra toplamlarına bakıldığında, deney grubunun ACTPKÖ izleme testi puanlarının plasebo ve kontrol grubunun АСТРКÖ izleme testi puanlarından anlamlı düzeyde düşük olduğu görülmektedir. Plasebo ve kontrol grupları arasında АCTPKÖ izleme testi puanlarında istatistiksel olarak anlamlı bir fark bulunmamıştır. Bu bulgular dikkate alındığında, deney grubuna uygulanan psikoeğitim programının zamana bağlı şekilde de ergenlerin akıllı cep telefonlarını problemli kullanımlarını azaltmada etkili olduğu söylenebilir.

\section{Psikoeğitim Programının Etkililiğine İlişkin Deney Grubunun Görüşle- rine İlişkin Bulgular}

Bu kısımda deney grubuna katılan öğrencilerin 11 haftalık psikoeğitim programının etkililiğine ilişkin görüşlerine yer verilmiştir.

Tablo 12. Deney Grubuna Katılan Öğrencilerin Psikoeğitim Programının Etkililiğine İlişkin Görüşleri

\begin{tabular}{lll}
\hline Alt temalar & Görüşler & f \\
\hline \multirow{4}{*}{ (i)Bireysel olumlu sonuçlar } & Zamanı iyi kullanma & 6 \\
& Farkındalık oluşması & 4 \\
& Özkontrol becerisinin artması & 4 \\
& Hayatına çekidüzen verme & 1 \\
\hline (ii) Akademik yaşamla ilgili & Ders çalışmanın artması & 4 \\
olumlu sonuçlar & Derste ögretmenleri dinlemenin artması & 1 \\
\hline (iii) Sosyal yaşamla ilgili olumlu & Aile içi ilişkilerde artma & 5 \\
sonuçlar & Sosyal ilişkilerin kalitesinde artma & 3 \\
\hline \multirow{2}{*}{ (iv) Sağlıkla ilgili olumlu sonuçlar } & Uyku kalitesinin artması & 2 \\
& Fiziksel problemlerin azalması & 1 \\
\hline \multirow{3}{*}{ (v) Gündelik olumlu sonuçlar } & Finansal sorun yaşamama & 4 \\
& Boş vakitlerinde cep telefonuyla ilgilenmeme & 2 \\
& Gereksiz uygulamaları silme & 2 \\
\hline
\end{tabular}

Deney grubuna katılan öğrencilerin psikoeğitim programının etkililiğine ilişkin görüşleri temasına bağlı olarak oluşturulan (i) bireysel olumlu sonuçlar, (ii) akademik yaşamla ilgili olumlu sonuçlar (iii) sosyal 
yaşamla ilgili olumlu sonuçlar, (iv) sağlıkla ilgili olumlu sonuçlar ve (v) gündelik olumlu sonuçlar alt temaları ve kodlar Tablo 12' de verilmiştir.

Deney grubu üyeleri, bireysel olumlu sonuçlar alt temasında sırasıyla zamanı iyi kullanma, farkındalı oluşması, özkontrol becerisinin artması ve hayatına çekidüzen verme faktörlerini belirtmişlerdir. Buna yönelik ifadeleri şu şekildedir:

- DGÜ4: Artık gerektiği zaman telefonla uğraşıyorum. . .

- DGÜ6: Kullanımım fazlaydı. Grup faaliyeti sayesinde farkındalık oluştu bende...

- DGÜ2: Elim aklım sürekli telefonda olurdu artık aklımda, elimde kendi kontrolümde...

- DGÜ1: Telefonun hayatımda neleri götürdü̆̈̈̈nü anladım ve hayatıma çekidüzen verdim...

Deney grubu üyeleri, akademik yaşamla ilgili olumlu sonuçlar alt temasında sırasıyla ders çalışmanın artması ve derste öğretmenleri dinlemenin artması faktörlerini belirtmişlerdir. Buna yönelik ifadeleri şu şekildedir:

- DGÜ7: Derslerime ilgi gösteremiyordum telefon yüzünden artı değişti...

- DGÜ10: Derste öğretmenlerin iyi anlatamadığını düşünüyordum ki öyle değilmiş ben dinlemediğim için anlamıyormuşum...

Deney grubu üyeleri, sosyal yaşamla ilgili olumlu sonuçlar alt temasında sırasıyla aile içi ilişkilerde artma ve sosyal ilişkilerin kalitesinde artma faktörlerini belirtmişlerdir. Buna yönelik ifadeleri şu şekildedir:

- DGÜ2: Akşamları babamla meyve yiyorum artık...

- DGÜ9: Sosyal ilişkilerimde etkililiğim arttı. Hatta grupta farkettiğim yaşantılarımı yakın arkadaşlarıma da farkettirmek için girişimlerim oldu...

Deney grubu üyeleri, sağllkla ilgili olumlu sonuçlar alt temasında sırasıyla uyku kalitesinin artması ve fiziksel problemlerin azalması faktörlerini belirtmişlerdir. Buna yönelik ifadeleri şu şekildedir:

- DGÜ1: Artık uykumu alabiliyorum...

- DGÜ4: Artık gözlerimin, boynumun ağrısının hatta parmak uyuşmalarımın nedenini farkettim. Artık eskisi kadar sıkıntılarım yok... 
Deney grubu üyeleri, gündelik olumlu sonuçlar alt temasında sırasıyla finansal sorun yaşamama, boş vakitlerinde cep telefonuyla ilgilenmeme ve gereksiz uygulamaları silme faktörlerini belirtmişlerdir. Buna yönelik ifadeleri şu şekildedir:

- DGÜ2: Artık TL yüklemek için ekstra para almıyorum ailemden. Babam bu durumdan çok mutlu olmuşa benziyor...

- DGÜ6: Boş vakitlerimi artık daha iyi değerlendiriyorum...

- DGÜ3:Telefonumda bulunan uygulamaları sildim...

Deney grubunun psikoeğitim programının etkiliğine ilişkin görüşleri yukarıda verilmiştir. Deney grubu üyelerinin yaşamlarında farklı alanlarda olumlu etkisinin olduğunu belirtmişlerdir. $\mathrm{Bu}$ belirtilenlerin yanında olumsuz olarak belirtilen bir şey olmuştur. Bir üye bazı dersleri kaçırdığını belirtmekle beraber grup sürecinin kendisi adına faydalı geçtiğini belirtmiştir. Grup üyeleri ayrıca böyle bir programın benzer durumda olan arkadaşlarına da uygulanmasının yararlı olacağından bahsetmişlerdir. Bir üye ise rehberlik saatlerinde okullarda bu tür faaliyetlerin yapılmasının yararlı olabileceğinden bahsetmiştir. Üyelerden grup sürecine ilişkin önerileri istendiğinde herhangi bir eklemeye gerek olmadığını belirtmişlerdir. Sadece bir üye ise her oturumun sonunda son oturumdaki gibi ikram olmasının daha iyi olacağını belirtmiştir.

\section{Sonuç ve Tartışma}

$\mathrm{Bu}$ bölümde araştıma kapsamında yapılan deneysel çalışmaya ilişkin sonuçlar verilmiş ve ilgili alanyazın dikkate alınarak tartışma yapılmıştır. Bunlara ek olarak, bu bölümde deney grubundaki üyelerin geliştirilen psikoeğitim programının etkililiğine ilişkin görüşleri de yer almaktadır. Yapılan analizler sonucunda elde edilen bulgulara göre;

a) Deneysel çalışmaya katılan deney, plasebo ve kontrol gruplarının ön test puanlarının birbirine denk olduğu bulunmuştur,

b) Deney grubu üyelerinin psikoeğitim programının sonu itibariyle akıllı cep telefonunun problemli kullanımı puanları, deney öncesine göre istatistiksel olarak anlamlı düzeyde azalmış ve bu azalma izleme ölçümlerinde de devam etmiştir, 
c) Plasebo grubunun, son test ve izleme testi puanları deney öncesindeki ön test puanına göre istatistiksel olarak anlamlı düzeyde azalmamiştır,

d) Kontrol grubunun da plasebo grubuna benzer şekilde son test ve izleme testi puanları deney öncesindeki ön test puanlarında istatistiksel olarak anlamlı düzeyde bir değişimin olmadığı bulunmuştur,

e) Deney grubunun akıllı cep telefonunun problemli kullanımına ilişkin son test puanlarının, plasebo ve kontrol gruplarının son test puanlarına göre istatistiksel olarak anlamlı düzeyde azalmıştır,

f) Ayrica deney grubunun akıllı cep telefonunun problemli kullanımına ilişin izleme testi puanlarının, plasebo ve kontrol gruplarının izleme testi puanlarına göre istatistiksel olarak anlamlı düzeyde azalmıştır.

Elde edilen bulgular birlikte değerlendirildiğinde; uygulanan 11 haftalık psikoeğitim programının ergenlerde akıllı cep telefonunun problemli kullanımını azalttığı söylenebilir. İlgili alanyazın incelendiğinde, Türkiye'de cep telefonunun problemli kullanımı üzerine yapılmış herhangi bir deneysel çalışmaya rastlanılmamıştır. Ayrıca dünyada cep telefonunun problemli kullanımı üzerine yapılan çok az sayıda deneysel çalışmaya rastlanılmıştır (Choi, 2015; Choi, Jang ve Lee, 2017; Lee, Seo ve Choi, 2016; Shin ve Jang, 2016; Yu ve Son, 2016). Choi (2015) üniversitede okuyan kadın öğrenciler ve kadın personelle akıllı cep telefonu bağımlılığını azaltmaya yönelik bir eğitim programı hazırlamıştır. Sekiz oturumun sonunda yaptıkları istatistiksel analizler sonucunda hazırlanan eğitim programının deney grubundaki katılımcıların akıllı cep telefonu bağımlılıklarını azaltmada etkili olduğunu bulmuştur. Shin ve Jang (2016) ergenler üzerine yapmış oldukları deneysel çalışmada grupla on oturumluk kum terapisinin ergenlerin akıllı cep telefonu bağımlıı̆ı̆ını azaltmada etkili olup olmadığını test etmişlerdir. Çalışmada uygulanan 10 oturumun ardından yapılan deneysel çalışmanın ergenlerin akıllı cep telefonu bağımlılığını azaltmada istatistiksel olarak anlamlı düzeyde etkili olduğunu bulmuşlardır. Lee, Seo ve Choi (2016) ortaokul öğrencileriyle iki haftalık ev temelli günlük gazete yazma aktivitesine dayalı deneysel çalışma yürütmüşlerdir. Yaptıkları deneysel çalışmanın ortaokul öğrencilerinin akıllı cep telefonu bağımlılığını azaltmada etkili olduğunu bulmuşlardır. Yu ve Son (2016) ise yaptıkları deneysel çalışmada kabul ve kararlılık terapisine dayalı olarak sekiz oturumluk bir program 
hazırlamışlardır. Hazırladıkları program yaptıkları ön-son test sonucuna göre bağımlılıklarını anlamlı şekilde azalttığını bulmuşlardır. Dört hafta sonraki izleme testinde de anlamlı etkinin devam ettiğini bulmuşlardır. Choi vd. (2017) öyküsel terapiye dayalı olarak hazırladıkları sekiz haftalık akıllı cep telefonu bağımlılığını önleme programını ergenlere uygulamışlardır. Yapılan analizler sonucunda ergenlerin akıllı cep telefonu bağımlılığı ölçeğinin yoksunluk, uyum sağlayıcı fonksiyonlarda bozulma ve tolerans geliştirme alt boyutlarında anlamlı düzeyde değişme olduğunu bulmuşlardır. Yapılan bu çalışmaların bulguları, araştırmanın bulgularıyla benzerlik gösterdiği söylenebilir. Alanyazında akıllı cep telefonlarının problemli kullanımına ilişkin deneysel çalışmaların yapılmasına ilişkin öneriler verilen araştırmalar (Choi, 2015; Fırat ve Balc1-Çelik, 2017; Kutlu ve Pamuk, 2017; Lee ve Lee, 2017; Pamuk, Kutlu ve Kuloğlu, 2016; Samaha ve Hawi, 2016; Tao vd., 2017; Yang, 2016) ve yapılan deneysel çalışmalar dikkate alındığında bu çalışmanın alanyazın için katkı sağlaması bağlamında önemli sayılabileceği söylenebilir.

Ergenler için akıllı cep telefonlarını problemli kullanımlarını azaltmaya ilişkin olarak hazırlanan psikoeğitim programının etkili olmasında, program hazırlanmadan önce bir nevi program öncesi ihtiyaç analizi yapılmış olmasının etkili olduğu söylenebilir. Bu ihtiyaç analizi çerçevesinde akıllı cep telefonunun problemli kullanımı kavramını derinlemesine incelemek amaciyla ergenlerle odak grup görüşmeleri, veli ve rehber öğretmenlerle de bireysel görüşmeler yapılarak akıllı cep telefonunun problemli kullanımına neden olan etmenler, problemli kullanım sonucu ortaya çıkan sonuçlar ve öneriler belirlenmiştir. Güçray, Çekici ve Çolakkadıŏ̆lu'na (2009) göre psikoeğitim gruplarında eğitime başlamadan önce uzun bir süre grubun ihtiyaçları üzerinde çalışılmalıdır. Araştırmada yapılan görüşmelerde hem akıllı cep telefonunun problemli kullanımı kavramı derinlemesine incelenmiş hem de hazırlanacak psikoeğitim programının içeriğinde neler olabileceğine dair fikirler edinilmiştir. Görüşmelerden elde edilen veriler analiz edildiğinde ergenlerin akıllı cep telefonlarını problemli kullanımlarında sadece ergene özgü faktörlerin değil, aile, okul, diğer birçok çevresel faktörün de etkili olduğu belirlenmiştir. Psikoeğitim programı hazırlanırken bu faktörler özellikle dikkate alınmıştır. Ancak faktörlerin bazıları programa farklı etkinlik veya tekniklerin uygulanması şeklinde dahil edilebilirken bazıları için bu mümkün olmamıştır. Örneğin, rehber öğretmenlerin belirttiği şekliyle ergenlerin zaman geçirebilecekleri mahallelerinde uygun alanların olmaması veya 
az olması ya da ebeveynlerin mahallelere güvenlik anlamında istismar, taciz gibi durumlardan dolayı bakışlarının olumsuz olabilmesi. Bu gibi faktörlerin psikoeğitim programına dahil edilmeleri mümkün olmamıştır. Program hazırlanırken bu şekilde bazı süzgeçlerden geçmiş olması ve oturumların buradaki faktörleri dikkate alarak hazırlanmış olması psikoeğitim programının ergenlerde etkili olmasında önemli faktörler olarak görülebilir.

Araştırmadan elde edilen sonuçlara göre hazırlanan psikoeğitim programının ergenlerde akıllı cep telefonunun problemli kullanım davranışlarını azaltmada istatistiksel olarak etkili olduğu söylenebilir. Bu etkililiğin deney grubuna katılan üyelerin psikoeğitim programının etkililiğine ilişkin görüşleriyle örtüştüğü söylenebilir. Üyelerin psikoeğitim programı sonrasında belirttikleri görüşleri dikkate alındığında üyelerinin yaşamlarında cep telefonu kullanımı nedeniyle sorun yaşadıkları birçok alanda (bireysel, akademik yaşam, sağlık, sosyal yaşam ve gündelik birtakım işler) olumlu gelişmeler olduğu görülmektedir. Deneysel çalışmanın etkililiğine ilişkin olarak hem nicel hem de nitel verilerden yararlanılmış olması ve nitel verilerin sonuçlarının nicel veri sonuçlarını destekler nitelikte olması araştırmanın artı yönü olarak değerlendirilebilir.

\section{Öneriler}

Son olarak, araştırmadan elde edilen bulgular doğrultusunda ergenlere ve araştırmacılara yönelik bazı önerilerde bulunulmuştur.

\section{Ergenlere Yönelik Öneriler}

1. İşlevleri az olan cep telefonları kullanabilirler.

2. Cep telefonu kullanım davranışlarını takip ve kontrol etmeleri bağlamında akıllı cep telefonlarına günlük, haftalık, aylık cep telefonu kullanımlarının istatistiğini tutan programlar kurarak ne kadar zamanda neler yaptıklarını objektif bir şekilde görme imkanları olabilir.

3. Akıllı cep telefonu kullanımları kontrollerinden çıkmaya başladığında okul rehber öğretmenlerinden yardım ve psikolojik destek alabilirler. 
4. Akraba ziyaretlerin sıklığını ve ziyaretlerin kalitesini arttırabilirler.

5. Arkadaşlarıyla daha sık ve kaliteli etkinliklere katılarak kaliteli zaman geçirebilirler.

6. Evde, okulda ve sosyal yaşam alanlarında cep telefonsuz anlar ve alanlar oluşturabilirler.

\section{Rehber Öğretmenlere Öneriler}

1. Hazırlanan psikoeğitim programını okullarındaki ergenlere uygulayabilirler.

2. Akıllı cep telefonunun problemli kullanımına ilişkin farkındalık oluşturucu afişler, broşürler asıp öğrencilere seminerler verebilirler.

3. Velilerde akıllı cep telefonlarının problemli kullanımlarına ilişkin farkındalık oluşturacak seminerler yapabilirler.

\section{Araştırmacılara Yönelik Öneriler}

1. Hazırlanan psikoeğitim programını farklı bölgelerdeki ergen gruplarına uygulayabilirler.

2. Bu psikoeğitim programın 10. sinıfların dışında 9, 11 ve 12 . siniflara uygulayabilirler.

3. Ergenlerin yaşadıkları fiziki çevrenin yetersizliğinin akıllı cep telefonlarını problemli kullanımlarındaki rolünü inceleyebilirler.

4. Akıllı cep telefonlarının problemli kullanımlarının bireylerin bilişsel işlev ve süreçleri üzerine etkisini inceleyebilirler. 


\title{
EXTENDED ABSTRACT
}

\section{Examination of The Effectiveness of A Psychoeducation Program to Reduce The Problematic Use of Smartphone in Adolescents}

*

\author{
Mustafa Pamuk - Mustafa Kutlu \\ Selçuk University - İnönü University
}

Nowadays, mobile phones are one of the most important technological devices used by many people. Mobile phones, especially smart mobile phones, include many possibilities for talking, sending text messages, sending e-mails, connecting to the internet, connecting to social networks, taking photos and videos, listening to MP3, watching TV as well as using as navigation and banking transactions offer (Pamuk ve Atli, 2016). Many people benefit from these services offered by mobile phones. However, when individuals start to use mobile phones excessively and more than necessary, apart from meeting the needs that may arise from the aforementioned conveniences, problematic use of mobile phones may arise.

Adolescents, also referred to as digital natives, who are in a critical period of development, may be said to be more familiar with technology, especially smartphones. It is thought that it is important for adolescents, families and the society to use their mobile phones in a healthy and functional way. When the related literature is taken into consideration, it is seen that problematic usage of smart mobile phones causes not only individual damages but also many negative consequences in academic, family life and social areas. In the related literature, it is seen that researchers have proposed to reduce or prevent programs for problematic use of smart mobile phones (Lian and You, 2017; Tao et al., 2017). When the literature is examined, it is seen that very few experimental studies related to problematic usage of smart mobile phones have been prepared and applied (Choi, 2015; Choi, Jang and Lee, 2017; Lee, Seo and Choi, 2016; Shin and Jang, 2016; Yu and Son, 2016). In Turkey it did not reveal any experimental work in this regard. In this context, it is considered important to prepare and implement a psychoeducation program to reduce problematic use of adolescents using problematic smartphones. It is 
thought that such a study will contribute both to the relevant literature and to adolescents using smartphones in this context.

\section{Method}

Mixed method was used in this study to investigate the effectiveness of the psychoeducation program developed to reduce the problematic use of smartphones in adolescents attending high school education. Mixed method research is a type of research that combines the elements of qualitative and quantitative approaches of a researcher or research group in the name of expansion of objectives, deep understanding and validation (Johnson, Onwuegbuzie and Turner, 2007). In this research, as shown in Figure 1, the embedded mixed research design, which is one of the mixed method research types, was used.
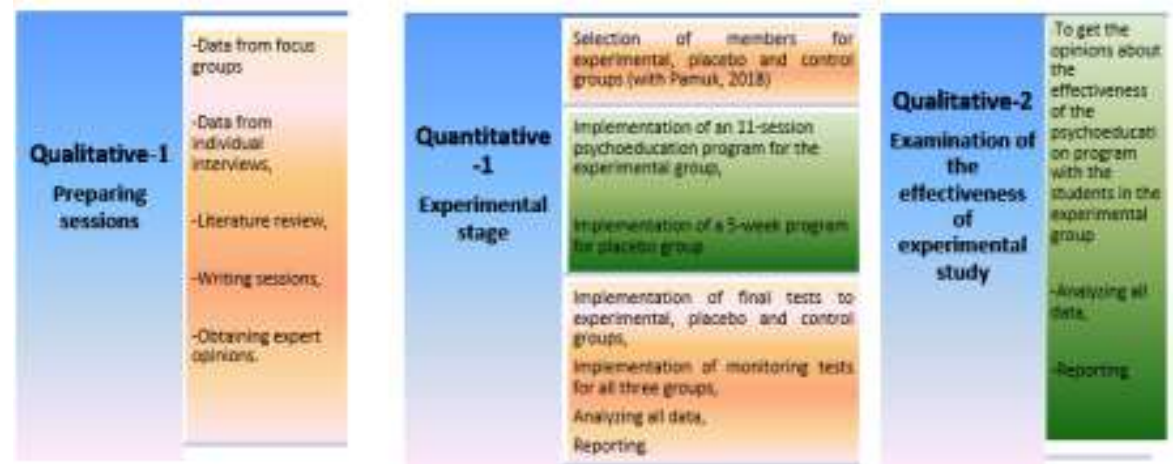

Figure 1. Embedded mixed research design

The research consists of three stages, and in the first stage (qualitative), the focus groups are three different focus groups, each of which consists of six

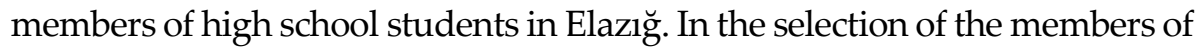
these three groups, the criterion sampling method was used "whose basic understanding is to study all the situations that meet a predetermined set of criteria (Yıldırım and Şimşek, 2008). Accordingly, in order to be a member of the group, the criteria of having a mean score above +1 standard deviation from the Problematic Use of Mobile Phone Scale (PUMPS) ( Güzeller and Coşguner, 2012), permission of parents and being voluntary criteria were 
taken into consideration. The first group is the parents of five students, in which individual interviews are held. Criterion sampling was used when selecting the parents. Accordingly, in the selection of the parents, the criteria of the children of parents having a score above +1 standard deviation from the PUMPS and the parents' volunteering were taken into consideration. In the first stage, the group of six people interviewed individually were guidance teachers. In the selection of guidance teachers, the snowball sampling method, which is effective in identifying individuals or situations that may be a rich source of information about the researcher's problem (Yıldırım \& Şimşek, 2008), was used. Accordingly, individual interviews were conducted with six guidance teachers by directing the guidance teachers to other guidance teachers who could share their knowledge and experience on the problematic use of the smartphones.

In the second stage of the research, data were collected from a total of 233 people, 112 of whom were male and 121 of which were female, for the selection of members in the experimental group. Out of 45 students who met the specified criteria, 30 students ( 22 female, 8 male) were selected as ten members to each groups (the experimental, placebo and control groups). The participants of the last phase of the study consisted of 10 people (8 girls and 2 boys) in the experimental group.

Problematic Cell Phone Use Scale Telefonu developed by Güzeller and Coşguner (2012) was used to determine the student members of the focus group interview. Problematic Use of Smartphones Scale developed by Pamuk (2017) for adolescents was used in the selection of experimental, control and placebo groups which were the second stage of the research and in evaluating the effectiveness of the program.

Qualitative and quantitative analysis techniques were used in different stages of the study. The data obtained from the focus group interview in the first stage of the research and the effectiveness of the psychoeducation group in the last stage were analyzed with Content Analysis. In the second stage of the research, quantitative analysis techniques were used. Kruskal Wallis $\mathrm{H}$ Test, Mann Whitney U Test, Friedman Rank Test and Wilcoxon Signed Ranks Test Based on Pairwise Comparisons were used in the experimental part of the second stage of the study. SPSS 22 program was used for data analysis. 
Before starting the first phase of the study, ethical permission was obtained from the Inonu University Ethics Committee of the Social and Humanities Scientific Research and Publication Ethics Committee. Then the necessary application permissions were obtained from Elazı̆ provincial directorate of national education.

\section{Preparing Sessions}

While preparing the Psychoeducation Program for Reducing Problematic Use of Smartphones, the literature was first examined. However, very few experimental studies on the problematic use of smartphones have been found (Choi, 2015; Choi, Jang and Lee, 2017; Lee, Seo and Choi, 2016; Shin and Jang, 2016; Yu and Son, 2016). Considering this, semi-structured interviews were conducted with adolescents, parents and counselors in order to better examine the concept of problematic use of smartphone which is a new concept in the research. In these semi-structured interviews, besides the concept, the factors that affect this problematic situation and the results of problematic use are tried to be determined. These studies were in the nature of needs analysis before the establishment of psychoeducation program. As a result of the interviews, 1.the problematic usage of smart mobile phone is not seen as a problem by adolescents, 2 . awareness of this problem is needed, 3.family factor is an important factor, 4 .this problem affects adolescents' lives in many areas, 5 . self-control skills related to the use of smartphones are low and 6. inefficient use of time.These factors play a role in problematic use of smart mobile phones in adolescents. Considering the factors that emerged as a result of the interviews, these factors were tried to be included in the sessions to the extent possible. In this context, it was possible to place some of the factors that emerged during the interviews in the sessions, but this did not apply to some factors. For example, nothing could be placed in sessions where families were bad role models for using mobile phones because parents were not involved in psychoeducation; however, the scenario, which was inspired by the focus group interviews, deals with the parent-adolescent conflict related to the problematic use of the smartphone, is placed in the sessions to be played with the role-playing technique.

The aim of the Psychoeducation Program for Reducing Problematic Use of Smartphones is to help adolescents to use their smartphones as much as 
they need and to become functional users. It is thought that the program prepared in line with the needs determined will be effective. In this process, a psychoeducation program consisting of 11 sessions was prepared with the members of the experimental group which lasted approximately 60-75 minutes on average. The sessions are planned to be held once a week, but in exam times, two sessions are planned in a week. The sessions of both the experimental and placebo groups were conducted by the reseacher.

In the psychoeducation program to reduce the problematic use of smart mobile phone, the following objectives are generally included:

To be able to see the results based on scientific evidences related to problematic use of smart mobile phone; to raise awareness about the negative effects of excessive use of smartphones by participants; to realize the moments when they intend to use their smartphones extensively and to find command sentences that they will use to combat them; to be aware of the activities they postponed or did not perform in their lives due to problematic use of smartphones; act as homework to carry out these postponed activities; to become aware of conflicts in family and school life due to excessive use of smartphones and to play a role in the context of experiencing the feelings experienced by the family members and people at school; mobile phones are not the place to solve the problems they face in everyday life and to realize that solving the problems is real life; to realize the difficulty of control when using smartphones and to take action in the context of dealing with this difficulty of control; to identify and to be aware of areas where it is not appropriate to use smartphones unless they are needed and to take action to deal with it; to determine when they use their smartphones routinely on a weekday and weekend and to plan for shifting these intensive times to other times and to make practice in real life fort the new programs and to be aware of the damages of using mobile phones as hidden. In short, this program focuses on raising awareness among adolescents, changing their perspectives, helping them to see their negative effects in daily life, encouraging them to be functional users, developing time management and self-control skills. The sessions were prepared, inspired by some cognitive behavioral techniques. 


\section{Findings}

According to ACTPKÖ pre-test between three groups there was no significant difference between the scores $\left(X^{2}=4.319, S d=2, n=10, p>\right.$. 05). According to this result, it is seen that the three groups are equivalent in terms of mean scores.

In the analysis with Friedman Rank Test, there was a statistically significant difference between the pretest, posttest and follow-up measurements of the experimental group students $\left(X^{2}=15.8 ; \mathrm{p}<.001\right)$. In order to determine this difference, paired groups were compared with Wilcoxon Signed Sequences Test. It was found that there was a significant difference between the pretest scores of the experimental group and the post-test scores of ACTPKÖ $(z=-$ $2,818 ; \mathrm{p}<.05)$. Posttest scores were significantly lower than the pre-test scores. Furthermore, there was also a significant difference between the pretest scores of the experimental group and the follow-up test scores $(z=-2.821 ; p$ $<.05)$. Follow-up test scores were significantly lower than the pre-test scores. According to another finding, there is no significant difference between posttest scores and follow-up test scores $(\mathrm{z}=-1.196 ; \mathrm{p}>.05)$. When these findings are evaluated together, it can be said that ACTPK scores of the experimental group decreased significantly at the end of the 11-session psychoeducation program and this decrease continued in the results obtained from the followup measurements six weeks after the end of the program.

In the analysis with Friedman Rank Test, pre-test, post-test and follow-up measurements of placebo group students, there was no statistically significant difference between $\left(X^{2}=3.405 ; \mathrm{p}>.05\right)$. This finding shows that the program of the efficient study conducted with placebo group did not have a significant effect on decreasing the scores obtained from ACTPKÖ. In the analysis with Friedman Rank Test, control group students' pre-test, post-test and follow-up measurements related to ACTPKÖ, there was no statistically significant difference between $\left(X^{2}=.389 ; \mathrm{p}>.05\right)$.

According to Kruskal Wallis $\mathrm{H}$ analysis of the posttest scores of the groups obtained from ACTPLS, a statistically significant difference was observed between the groups $\left(X^{2}=19.505 ; \mathrm{Sd}=2 ; \mathrm{p}<.05\right)$. MannWhitney $\mathrm{U}$ Test was applied to determine which group or groups this difference is related to. According to the results of the Mann Whitney $U$ test, it was found that there was a significant difference between the post-test scores of the experimental group and the post-test scores of the placebo group $(U=, 000 ; \mathrm{p}<.01)$ and control group 
$(\mathrm{U}=, 000 ; \mathrm{p}<.01)$. It is seen that ACTPKÖ posttest scores of experimental group were significantly lower than placebo and control group ACTPKÖ posttest scores.

According to Kruskal Wallis $\mathrm{H}$ analysis, it was observed that there was a statistically significant difference between the groups $\left(X^{2}=20,263 ; S d=2 ; p\right.$ $<.05)$. MannWhitney U Test was applied to determine which group or groups this difference is related to. According to the results of Mann Whitney $U$ test, it was found that there was a significant difference between the ACTPKÖ follow-up test scores of the experimental group and the follow-up test scores of the placebo group $(U=, 000 ; p<.01)$ and control group $(U=, 000 ; p<.01)$. It was observed that the ACTPKÖ follow-up test scores of the experimental group were significantly lower than the ACTPKÖ follow-up test scores of the placebo and control groups.

Tablo 1.The Opinions of the Students Participating in the Experimental Group on the Effectiveness of the Psychoeducation Program

\begin{tabular}{lll}
\hline Sub themes & Opinions & f \\
\hline \multirow{4}{*}{ (i) Individual positive results } & Use time efficiently & 6 \\
& Raising awareness & 4 \\
& Increase of self-control ability & 4 \\
& Rearrange their lives & 1 \\
\hline \multirow{2}{*}{ (ii) Positive results about academic life } & Increased course study & 4 \\
& Increased listening to teachers in class & 1 \\
\hline \multirow{2}{*}{ (iii) Positive results about social life } & Positive developments in family relations & 5 \\
& Improving the quality of social relations & 3 \\
\hline \multirow{2}{*}{ (iv) Positive health outcomes } & Increase the quality of sleep & 2 \\
& Reduction of physical problems & 1 \\
\hline \multirow{3}{*}{ (v) Daily positive results } & No financial problems & 4 \\
& Not interested in mobile phone in their spare & 2 \\
& time & 2 \\
\hline
\end{tabular}

\section{Conclusion and discussion}

When the findings obtained are evaluated together; It can be said that the 11week psychoeducation program reduces the problematic use of smartphones in adolescents. When examining related literature, there was no any experimental work in Turkey related to problematic use of smartphones. In addition, very few experimental studies on problematic use of mobile phones 
have been found in the world (Choi, 2015; Choi, Jang and Lee, 2017; Lee, Seo and Choi, 2016; Shin and Jang, 2016; Yu and Son, 2016). It can be said that this study can be considered important in the context of contributing to the literature.

According to the results of the study, it can be said that psychoeducation program is statistically effective in reducing problematic behaviors of smart mobile phone in adolescents. It can be said that this effectiveness coincided with the opinions of the members of the experimental group regarding the effectiveness of the psychoeducation program. When the opinions of the members after the psychoeducation program are taken into consideration, it is seen that there are positive developments in many areas (individual, academic life, health, social life and daily works) where the members had problems due to the use of mobile phones in their lives. The fact that both quantitative and qualitative data have been utilized for the effectiveness of the experimental study and that the results of the qualitative data support the results of the quantitative data can be considered as a plus aspect of the research.

\section{Kaynakça / References}

Augner, C. ve Hacker, G. W. (2012). Associations between problematic mobile phone use and psychological parameters in young adults. International Journal of Public Health, 57(2), 437-441.

Chiu S. I., Lee J. Z. ve Huang, D. H. (2004). Video game addiction in children and teenagers in Taiwan. CyberPsychology \& Behavior, 7(5), 571-581.

Choi, N. (2015). The Effects of a smartphone addiction education program for young adult females. International Journal of $u$-and e-Service, Science and Technology, 8(12), 277-284.

Choi, I. H., Jang, M. J. ve Lee, D. M. (2017). Development of narrative therapy counseling program for prevention of adolescents' smartphone addiction. Journal of The Korean Society for Computer Game, 30(1), 11-23.

Creswell, J. W. ve Plano Clark, V. L. (2015). Karma yöntem araştırmaları tasarımı ve yürütülmesi. (Y. Dede ve SB Demir, Çev. Ed.). Ankara: Anı Yayıncılık. (Orijinal Basım 2011). 
Çağan, Ö., Ünsal, A. ve Çelik, N. (2014). Evaluation of college students' the level of addiction to cellular phone and investigation on the relationsship between the addiction and the level of depression. Procedia-Social and Behavioral Sciences, 114, 831-839.

Çetin, F. H., Pamuk, M. ve Donmuş, V. (2015). Ergenlerde problemli cep telefonu kullanımı ile akademik erteleme arasındaki ilişkide internet bağımlılığının aracılık rolünün incelenmesi. Çocuk ve Gençlik Ruh Sağhlğ Dergisi, 22(1), 61.

Erdogan, U., Pamuk, M., Eren-Yuruk, S. ve Pamuk, K. (2013, 17-18 October). Academic procrastination and mobile phone. Paper presented at International Academic Conference on Education, Teaching and E-learning, Czech Republic.

Erkan, S. ve Kaya, A. (2005). Deneysel olarak sınanmış grupla psikolojik danışma ve rehberlik programları II. (1. Baskı). Ankara: Pegem Akademi.

Erkan, S. ve Kaya, A. (2009). Deneysel olarak sınanmış grupla psikolojik danışma ve rehberlik programları III. (2. Baskı). Ankara: Pegem Akademi.

Erkan, S. ve Kaya, A. (2015a). Deneysel olarak sınanmış grupla psikolojik danışma ve rehberlik programları I. (5. Bask1). Ankara: Pegem Akademi.

Erkan, S. ve Kaya, A. (2015b). Deneysel olarak sınanmış grupla psikolojik danışma ve rehberlik programları III. (1. Baskı). Ankara: Pegem Akademi.

Fırat, N. ve Çelik, S. B. (2017). Cep telefonu bağımlılığı ölçeği (CBÖ)'nin Türkçe'ye uyarlanması: Geçerlik ve güvenirlik çalışması. Journal of Human Sciences, 14(3), 2875-2887.

Güçray, S.S., Çekici, F. ve Çolakkadığlu, O. (2009). Psikoeğitim gruplarının yapılandırılması ve genel ilkeleri. Mersin Üniversitesi Eğitim Fakültesi Dergisi, 5(1), 134-153.

Günüç, S. ve Kayri, M. (2010). Türkiye'de internet bağımlılık profili ve internet bağımlılık ölçeğinin geliştirilmesi: Geçerlik-güvenirlik çalışması. Hacettepe Üniversitesi Ĕ̆itim Fakültesi Dergisi, 39, 220-232.

Güzeller, C.O., ve Coşguner, T. (2012). Development of a problematic mobile phone use scale for Turkish adolescents. Cyberpsychology, Behavior, and Social Networking, 15(4), 205-211.

Hadlington, L. J. (2015). Cognitive failures in daily life: Exploring the link with internet addiction and problematic mobile phone use. Computers in $\mathrm{Hu}$ man Behavior, 51, 75-81. 
Hayırcı, B. (2019). Lise öğrencilerinin akıllı telefon bağımlılık düzeyleri ile sosyal kaygı ve yalnızlk düzeyleri arasındaki ilişkinin incelenmesi. (Yayımlanmamış Yüksek Lisans Tezi). Ordu ÜniversitesiSosyal Bilimler Enstitüsü, Ordu.

Hong, F. Y., Chiu, S. I., ve Huang, D. H. (2012). A model of the relationship between psychological characteristics, mobile phone addiction and use of mobile phones by Taiwanese university female students. Computers in Human Behavior, 28(6), 2152-2159.

Jenaro, C., Flores, N., Gómez-Vela, M., González-Gil, F. ve Caballo, C. (2007). Problematic internet and cell-phone use: Psychological, behavioral, and health correlates. Addiction research \& theory, 15(3), 309-320.

Johnson, R.B., Onwuegbuzie, A.J. ve Turner, L.A. (2007). Toward a definition of mixed methods research. Journal of mixed methods research, 1(2), 112-133.

Kaltiala-Heino, R., Lintonen, T. ve Rimpelä, A. (2004). Internet addiction? Potentially problematic use of the Internet in a population of 12-18 yearold adolescents. Addiction Research E Theory, 12(1), 89-96.

Kubey, R. ve Csikszentmihalyi, M. (2002). Television addiction. Scientific American, 286(2), 74-81.

Kutlu, M. ve Pamuk, M. (2017). Üniversite öğrencilerinde cep telefonunun problemli kullanımının kişilik bağlamında incelenmesi. Uluslararası Insan Bilimleri Dergisi, 14(2), 1263-1272.

Lee, C. ve Lee, S. J. (2017). Prevalence and predictors of smartphone addiction proneness among Korean adolescents. Children and Youth Services Review, $77,10-17$.

Lee, H., Seo, M.J. ve Choi, T.Y. (2016). The Effect of home-based daily journal writing in Korean adolescents with smartphone addiction. Journal of Korean medical science, 31(5), 764-769.

Lemmens, J. S., Valkenburg, P. M. ve Gentile, D. A. (2015). The Internet gaming disorder scale. Psychological assessment, 27(2), 567-582.

Lian, L. ve You, X. (2017). Specific virtues as predictors of smartphone addiction among chinese undergraduates. Current Psychology, 36, 376-384.

Mert, A. ve Özdemir, G. (2018). Yalnızlık duygusunun akıllı telefon bağımlılığına etkisi. OPUS-Uluslararası Toplum Araştırmaları Dergisi, 8(1), 88-107.

O'Connor, S. S., Whitehill, J. M., King, K. M., Kernic, M. A., Boyle, L. N., Bresnahan, B. W., ... Ebel, B. E. (2013). Compulsive cell phone use and history of motor vehicle crash. Journal of Adolescent Health, 53(4), 512-519. 
Özen, S. ve Topcu, M. (2017). Tip fakültesi öğrencilerinde akıllı telefon bağımlılı̆̆ ile depresyon, obsesyon-kompulsiyon, dürtüsellik, aleksitimi arasındaki ilişki. Bă̆ımlılık Dergisi, 18(1), 16-24.

Pamuk, M. (2017). Ergenlerde akıll cep telefonunun problemli kullanımın azaltmaya yönelik bir psikoeğitim programın etkililiğinin incelenmesi. (Yayımlanmamış Doktora Tezi). İnönü Üniversitesi Eğitim Bilimleri Enstitüsü, Malatya.

Pamuk, M. ve Atli, A. (2016). Development of a problematic mobile phone use scale for university students: Validity and reliability study. Düşünen Adam: The Journal of Psychiatry and Neurological Sciences, 29(1), 49-59.

Pamuk, M., Kutlu, M. ve Kuloğlu, A. (2016, 3-5 Kasım). Üniversite öğrencilerinde cep telefonunun problemli kullanımı ve öğrenci tükenmişliği. I. International Academic Research Congress'te sözlü bildiri olarak sunulmuştur, Antalya.

Roser, K., Schoeni, A., Foerster, M. ve Röösli, M. (2016). Problematic mobile phone use of Swiss adolescents: is it linked with mental health or behaviour?. International journal of public health, 61, 307-315.

Sahin, S., Ozdemir, K., Unsal, A. ve Temiz, N. (2013). Evaluation of mobile phone addiction level and sleep quality in university students. Pak J Med Sci, 29,4,913-918.

Samaha, M. ve Hawi, N. S. (2016). Relationships among smartphone addiction, stress, academic performance, and satisfaction with life. Computers in Human Behavior, 57, 321-325.

Shin, J. H. ve Jang, M. (2016). Effect of group sandplay therapy to be addicted youth's addiction levels and anxiety. Journal of Symbols \& Sandplay Therapy, 7(1), 39-55.

Şar, A. H. (2013). Examination of loneliness and mobile phone addiction problem observed in teenagers from the some variables. The Journal of Academic Social Science Studies, 6(2), 1207-1220.

Tan, Ç., Pamuk, M. ve Dönder, A. (2013). Loneliness and mobile phone. Procedia-Social and Behavioral Sciences, 103, 606-611.

Tao, S., Wu, X., Zhang, Y., Zhang, S., Tong, S. ve Tao, F. (2017). Effects of sleep quality on the association between problematic mobile phone use and mental health symptoms in Chinese college students. International journal of environmental research and public health, 14(2), 185, 1-10. 
Tohumcu, M. U., Karsli, T. A., Bahadir, E. ve Kalender, B. (219). İnternet ve akıllı telefon bağımlılığı ile benlik saygısı ve yalnızlık arasındaki ilişkinin incelenmesi. Trakya Üniversitesi Sosyal Bilimler Dergisi, 21(2), 773-787.

Türkiye İstatistik Kurumu (2016). Hanehalkı bilişim teknolojileri kullanım araştırması, 2016, Sayı: 21779. http://www.tuik.gov.tr/ PreHaberBultenleri. do?id=21779 . Erişim Tarihi: 24 Aralık, 2017.

Wang, J. L., Wang, H. Z., Gaskin, J. ve Wang, L. H. (2015). The role of stress and motivation in problematic smartphone use among college students. Computers in Human Behavior, 53, 181-188.

Wang, C.C. ve Yang, H.W.(2007). Passion and dependency in online shopping activities. CyberPsychology E Behavior, 10(2), 296-298.

Yang, K.M. (2016). The effect of self-esteem and depression on smartphone addiction among university students. Journal of the Korea Convergence Society, 7(1), 113-123.

Yang, Y. S., Yen, J. Y., Ko, C. H., Cheng, C. P. ve Yen, C. F. (2010). The association between problematic cellular phone use and risky behaviors and low self-esteem among Taiwanese adolescents. BMC public health, 10(1), 1-8.

Yıldırım, A. ve Şimşek, H. (2008). Sosyal bilimlerde nitel arastirma yöntemleri. Seçkin Yayıncilik.

Yılmaz, G., Şar, A.H. ve Civan, S. (2015). Investigation of adolescent mobile phone addiction by social anxiety effect of some variable. Online Journal of Technology Addiction \& Cyberbullying, 2(2), 20-37.

$\mathrm{Yu}$, H.G. ve Son, C. (2016). Effects of ACT on smartphone addiction level, selfcontrol, and anxiety of college students with smartphone addiction. Journal of Digital Convergence, 14(2), 415-426.

\section{Kaynakça Bilgisi / Citation Information}

Pamuk, M. ve Kutlu, M. (2020). Ergenlerde akıllı cep telefonunun problemli kullanımını azaltmaya yönelik bir psikoeğitim programının etkililiğinin incelenmesi. OPUS-Uluslararası Toplum Araştırmaları Dergisi, 15(21), 56-95. DOI: 10.26466/opus.621117 